\title{
PRAKTEK DAN KEBIJAKAN MANAJEMEN SUMBER DAYA MANUSIA PADA PERBANKAN SYARIAH
}

\author{
Tri Wikaningrum \\ Fakultas Ekonomi Universitas Islam Sultan Agung \\ e-mail: lafaya_dea@yahoo.com
}

\begin{abstract}
The purpose of this study is to identify policies and practices of Human Resource (HR) development at shariah bank; then analyze their influence into organizational performance. Variables of this study are policies and practices of HR development, work attitude, selection, training, development, policy formalization, communication, promotion, compensation, and performance appraisal. Data were collected by using in-depth interview and survey questionnaire. Interviews were conducted to management, while questionnaires were distributed to 70 employees. Data were analyzed by using descriptive method. Result shows less optimal of HR management practices in most of the respondent of syariah banks; these including the allocation of training time and frequency of execution, clarity of the basis for setting promotion, the type and amount of compensation that is less competitive when compared with the same type of job in another bank, and performance appraisals that are less oriented toward employee development.
\end{abstract}

Key words: policies and practices of HR management, shariah bank, performance, employee development.

\begin{abstract}
Abstrak
Tujuan penelitian ini adalah untuk mengidentifikasi kebijakan dan praktek pengembangan Sumber Daya Manusia (SDM) di bank syariah, kemudian menganalisis pengaruhnya terhadap kinerja organisasi. Variabel penelitian ini adalah kebijakan dan praktek pengembangan SDM, sikap kerja, seleksi, pelatihan, pengembangan, formalisasi kebijakan, penilaian kinerja, promosi, kompensasi, dan kinerja. Data dikumpulkan dengan menggunakan wawancara mendalam dan kuesioner. Wawancara dilakukan untuk manajemen, sementara kuesioner dibagikan kepada 70 karyawan. Data dianalisis menggunakan metode deskriptif. Hasil analisis menunjukkan bahwa praktik manajemen SDM bagi sebagian besar responden bank syariah kurang optimal. Hal ini termasuk alokasi waktu pelatihan dan frekuensi pelaksanaan, kejelasan dasar untuk pengaturan promosi, jenis dan jumlah kompensasi yang kurang kompetitif bila dibandingkan dengan jenis pekerjaan yang sama di bank lain, serta penilaian kinerja yang kurang berorientasi pada pengembangan karyawan.
\end{abstract}

Kata kunci: kebijakan dan praktek manajemen SDM, bank syariah, kinerja, pengembangan karyawan.

\section{PENDAHULUAN}

Pada kondisi krisis ekonomi, tantangan setiap organisasi untuk bisa bertahan dan berkembang semakin besar. Ketika faktor eksternal semakin sulit diprediksi dan dikontrol, pengelolaan internal organisasi termasuk pemberdayaan potensi sumber daya manusia menjadi krusial. Praktek manajemen sumber daya manusia yang ada harus bisa mendukung penciptaan sikap kerja dan perilaku yang menguntungkan bagi organisasi. Sebagaimana sejumlah penelitian berhasil menguji pengaruh positif yang erat dari praktek SDM terhadap kinerja organisasional. Pada prakteknya pun manajemen SDM menjadi alat manajemen strategis yang penting selama periode resesi ekonomi.

Kualitas sumber daya manusia (SDM) dalam melayani pelanggan berperan penting dalam menentukan kinerja organisasional. Tentu saja SDM yang berkualitas tidak bisa 
hanya mengandalkan pengetahuan dan keahlian bawaan yang sudah mereka miliki ketika bergabung dengan perusahaan. Perlu praktek internal perusahaan yang mengarah pada tujuan mengembangkan kapabilitas (skill dan ability karyawan, meningkatkan motivasi karyawan dalam menjalankan upaya discretionary, serta memberikan peluang penuh bagi penggunaan knowledge, skill, dan berbagai atribut lainnya pada pekerjaan mereka. Iklim yang demikian akan menguatkan persepsi karyawan mengenai seberapa baik praktek dan prosedur yang ada memudahkan penyampaian servis yang excellent ke pelanggan. Selain itu juga persepsi mengenai kualitas pelayanan yang diharapkan perusahaan serta dukungan dan reward dari pihak manajemen bagi karyawan atas kinerja mereka. Sebagaimana pernyataan Schneider and Bowen (1985), bahwa suatu studi yang mengkaji praktek organisasional di sejumlah bank menunjukkan bahwa hubungan praktek Human Resource Management (HRM) dengan outcomes organisasional di perusahaan jasa sangatlah kuat. Pada perusahaan manufaktur, kualitas produk secara langsung dipengaruhi oleh investasi teknologi ataupun kontrol proses pabrikan. Dengan demikian perilaku kerja karyawan hanya berdampak secara marjinal terhadap kualitas. Namun tidak demikian halnya pada perusahaan jasa, yang meskipun didukung teknologi tetap saja tidak bisa menggantikan interaksi karyawan-pelanggan secara face-to-face.

Praktek HRM itu sendiri, mempengaruhi persepsi karyawan mengenai seberapa besar perusahaan tempatnya bekerja memperhatikan well-being mereka dan percaya bahwa sumber daya yang telah mereka berikan pada organisasi akan dibalas melalui kebijakan di bidang MSDM. Penetapan kompensasi yang fair, program training yang berkelanjutan, penilaian kinerja yang berdampak pada pengembangan karyawan, dan kualitas komunikasi dengan atasan misalnya, mempersepsi kan dirinya diperlakukan dengan baik oleh organisasi. Karyawan akan merasa berkewajiban untuk memperlakukan organisasi dengan baik \& mencoba menghindari tindakan yang merugikan organisasinya (Gouldner, 1960). Dengan kata lain, para karyawan merasa berkewajiban membalas untuk menciptakan keseimbangan dalam pertukaran dengan organisasi.
Utamanya pada perbankan yang bergerak di bidang jasa, yang mana unsur people melakukan interaksi tinggi dengan pelanggan, maka kualitas pelayanan yang disampaikan tidak bisa lepas dari peran para karyawan yang menjadi sumber daya manusia di dalamnya. Bagaimana perilaku, intensi, dan sikap karyawan mengarah pada high quality service, secara strategis bisa diarahkan melalui praktek dan kebijakan dalam manajemen SDM yang ada. Oleh karenanya bisa diterima bahwa praktek-praktek internal dalam suatu organisasi termasuk praktek dan kebijakan dalam manajemen sumber daya manusia memiliki potensi berdampak pada kinerja organisasi yang bersangkutan.

Kompetisi pada industri perbankan khususnya perbankan syariah tidak hanya diantara bank umum syariah. Yang banyak pemainnya justru bank konvensional lokal maupun asing yang membuka Unit Usaha Syariah (UUS). Tentu saja kondisi persaingan ini menuntut masing-masing bank untuk meningkatkan kualitas pelayanannya kepada masyarakat. Sebagai perusahaan jasa, nasabah/pelanggan terlibat dalam proses penyampaian jasa dan adanya interaksi dekat antara karyawan dengan pelanggan. Itulah kenapa faktor SDM di bidang jasa sangat penting karena tidak bisa sepenuhnya tergantikan oleh teknologi. Apalagi hubungan dengan nasabah pada bank syariah lebih pada kemitraan yang berorientasi bukan hanya profit semata, tapi juga falah oriented alias kebahagiaan di akhirat. Berbeda dengan di bank konvensional yang berbentuk hubungan debitor-kreditor. Oleh karena sifat reputational risk yang tinggi tersebut menempatkan pentingnya praktek SDM yang ada bagi peningkatan kinerja pada bank syariah. Sebagaimana pernyataan Devanna, Fombrun, dan Tichy (1984 dalam Zerbe, Dobni, \& Harel, 1998) bahwa aktivitas SDM memiliki dampak besar bagi kinerja individual yang selanjutnya berkontribusi terhadap produktivitas dan kinerja organisasional. Argumen tersebut menjadi dasar keyakinan utama mengenai peran praktek SDM bagi kinerja organisasional.

Banyak penelitian yang mengkaji hubungan HRM practices dengan kinerja organisasional, terutama pada industri manufaktur. Namun, studi mengenai peran trust 
sebagai mediator diantara kedua variabel tersebut masih terbatas. Penelitian ini mengkaji hubungan praktek manajemen SDM dengan kepercayaan karyawan terhadap atasan dan organisasi, yang dapat mempengaruhi besarnya komitmen karyawan pada organisasi dan kepuasan kerjanya. Sikap kerja yang positif pada akhirnya diduga akan meningkatkan kinerja individual karyawan. Ada beberapa hal yang melatarbelakangi konsep berpikir tersebut. Pertama, beberapa tahun terakhir ini semakin mengemuka tingginya job insecurity bagi karyawan pada industri perbankan. Itu akan mempengaruhi tingkat kepercayaan karyawan terhadap organisasinya. Juga mempengaruhi kepercayaan terhadap atasan langsungnya, jika kebijakan dan sikap atasan dipersepsikan tidak mendukung well-being mereka. Mengulang kembali pernyataan sebelumnya, bahwa praktek yang sama dapat menimbulkan konsekuensi berbeda tergantung pada kecenderungan persepsi atau pemikiran karyawan. Jadi, ketika trust karyawan berbeda, maka praktek yang ada akan mempengaruhi sikap kerja yang berbeda pula. Kedua, terkait dengan aspek interaksi tinggi antara pelanggan jasa dengan perusahaan melalui SDM-nya, maka menjadi lebih dapat diterima bahwa hubungan tersebut dimediasi oleh perilaku dan sikap karyawan. Namun belum ada yang menguji trust sebagai variabel pemediasi dalam hubungan tersebut. Ketiga, membangun trust menjadi hal yang penting mengingat kurangnya kepercayaan karyawaan terhadap perusahaannya berdampak pada outcomes disfungsional, seperti komitmen rendah, motivasi yang juga rendah, serta kurangnya kepercayaan di antara pihak-pihak yang berinteraksi.

Peningkatan jumlah dan aset perbankan syariah menunjukkan kemampuannya bersaing dengan bank konvensional. Sayangnya, perkembangan tersebut belum diimbangi oleh kesiapan sumber daya insani yang memadai. Bahkan Direktur Direktorat Perbankan Syariah Bank Indonesia mengakui bahwa secara umum, perbankan syariah memang menghadapi masalah dengan SDI. Mengingat bank syariah menghadapi reputational risk, maka perhatian terhadap pengembangan SDM secara terencana dan berkelanjutan harus ditingkatkan.

\section{KAJIAN PUSTAKA}

\section{Kumpulan Praktek MSDM dan Kinerja}

Schneider and Bowen (1985) mendapatkan bahwa persepsi karyawan mengenai praktekpraktek MSDM secara signifikan berhubungan dengan persepsi pelanggan mengenai kualitas pelayanan. Ketika para karyawan merasa diperlakukan dengan baik oleh praktek MSDM yang ada, maka mereka akan dapat mencurahkan energi dan sumber dayanya untuk melayani pelanggan secara efektif. Studi yang dilakukan oleh Schneider and Bowen (1985) mengenai praktek organisasional di kantorkantor cabang, menemukan bahwa hubungan antara praktek MSDM dan outcomes strategik paling kuat pada organisasi jasa.

Praktek-praktek MSDM dapat meningkatkan "value" karyawan pada suatu organisasi. Praktek seleksi misalnya, memiliki peran penting dalam mendapatkan tenaga kerja yang berkualitas yang memenuhi kualifikasi yang dibutuhkan perusahaan. Untuk itu selama proses seleksi, perusahaan harus berupaya menemukan dan menarik calon karyawan yang berkeahlian dan sikap serta perilaku yang mendukung nilai-nilai dan pencapaian tujuan organisasi. Tantangan selanjutnya adalah mempertahankan keberadaannya dalam jangka panjang. Pelatihan dan pengembangan juga kritis bagi pencapaian kinerja organisasional dan keunggulan bersaing perusahaan (De Saaperes \& Garcia-Falcon, 2002). Pelatihan juga praktek yang baik dalam mengatasi faktorfaktor yang menurunkan kepuasan kerja dan kinerja karyawan. Guna mencapai efektivitas training, program pelatihan haruslah fit dengan proses kerja dan strategi perusahaan. Pasca pelatihan pun harus dipastikan terjadi transfer pelatihan yang mendukung proses pembelajaran karyawan. Selanjutnya, upaya pembelajaran oleh karyawan yang mendukung peningkatan kinerja harus diperhatikan rewardnya (Guest, 1997). Hal ini didukung oleh banyak studi yang menemukan bahwa insentif berpengaruh terhadap kinerja organisasional. Tujuan secara umum dari pemberian insentif itu sendiri adalah merubah perilaku, meningkatkan sikap positif dan memotivasi karyawan hingga dapat berkontribusi terhadap pertumbuhan perusahaan.

Sejumlah studi menyatakan bahwa sistem SDM yang mendukung aktivitas tim 
kerja merupakan praktek yang kritis bagi inovasi dan daya saing organisasional (Lau \& Ngo, 2004). Selagi aktivitas tim mendorong kerjasama dan komunikasi di antara karyawan, pada saat yang sama aktivitas itupun mendukung penciptaan budaya kerja yang tepat. Kemudian, umpan balik atas kinerja mereka menjadi praktek yang diperlukan atasan langsung dalam meningkatkan keefektifan kerja bawahannya. Berbagi informasi mengenai kinerja individual karyawan pada praktek tersebut menjadi sarana meningkatkan komunikasi di antara kedua pihak, sehingga secara efektif mengarah pada keterbukaan komunikasi organisasional. Semua praktek manajemen SDM yang telah diuraikan tersebut meningkatkan trust karyawan pada perusahaannya. Antara satu praktek dengan praktek lainnya saling mendukung dan menguatkan pencapaian kinerja organisasional (Zerbe, Dobni, \& Harel, 1998).

Kinerja merupakan fungsi dari semua komponen sumber daya manusia. Artinya, pengelolaan terhadap SDM akan menentukan bagaimana kinerja yang dicapai organisasi bersangkutan. Komponen itu diantaranya meliputi: menseleksi calon karyawan terbaik, menilai kinerja karyawan guna menjamin distribusi reward yang adil, memotivasi karyawan dengan mengkaitkan reward dan tingkat kinerja, dan mengembangkan karyawan agar meningkat kinerjanya pada posisi pekerjaan yang mereka tangani sekarang.

\section{Trust dan Praktek Manajemen Sumber Daya Manusia}

Trust merupakan komponen kunci dari organizational relationship yang memiliki keberartian baik secara akademis maupun praktis. Sejumlah literatur yang ada pun mengakui bahwa trust berpengaruh signifikan terhadap produktivitas organisasional (Mayer \& Davis, 1999; Prusak \& Cohen, 2001). Banyak juga riset yang berfokus pada cara mengembangkan dan meningkatkan kepercayaan diantara para karyawan, menunjukkan bahwa organisasi memandang trust debagai variabel yang dibutuhkan sekali keberadaannya. Sebagai contoh, Konovsky and Pugh (1994) menunjukkan bahwa kepercayaan pada manajer berpengaruh positif terhadap proses pertukaran sosial. Temuan ini didukung hasil penelitian
Aryee, Budhwar, and Chen (2002) yang menemukan bahwa kepercayaan pada organisasi berhubungan dengan sikap kerja seperti komitmen organisasional dan kepuasan kerja. Sejumlah peneliti bahkan merumuskan bahwa harapan manajerial yang positif akan diwujudkan dalam perilaku manajerial seperti memfasilitasi pelatihan dan memberi peluang partisipasi dalam proses pengambilan keputusan (Liden, Wayne, \& Stilwell, 1993). Pernyataan kebijakan yang diambil manajerial terkait dengan praktek SDM tersebut yang tentunya berdampak bagi karyawan, akan menentukan tingkat kepercayaan karyawan terhadap atasan dan organisasinya.

Konstruk trust pada hubungan pekerjaan mencakup 3 dimensi, yaitu harmony, reliability, dan concern (Tzafrir \& Dolan, 2004). Pertama harmoni, terkait pemikiran akan kepemilikan identitas dan nilai bersama. Reliabilitas sebagai dimensi kedua, berarti bahwa pihak yang mempercayai memiliki harapan positif mengenai konsistensi antara kata dan tindakan pihak yang dipercaya. Dimensi ketiga, perhatian, mengarah pada pemikiran mengenai sejauhmana kepentingan diri diseimbangkan dengan kepentingan pihak lain. Jadi dapat diambil kesimpulan bahwa ketika seorang karyawan memiliki trust yang tinggi pada atasan dan organisasinya, maka berpotensi mendorong keinginan untuk meningkatkan sumber daya yang diberikan bagi pihak lain, berdasarkan harapan positif yang didorong oleh saling interaksi positif sebelumnya.

Banyak teori mengenai trust yang merupakan pembahasan dalam teori pertukaran sosial. Sedangkan praktek manajemen menjadi bagian penting dari pertukaran sosial yang mencirikan hubungan pemekerjaan, dimana komponen trust terlibat di dalamnya. Pada seting organisasional, adanya saling percaya berpotensi meningkatkan kerjasama, dan mendorong tindakan berbagi informasi di antara karyawan dan manajernya, bahkan di antara unit organisasi yang pada akhirnya meningkatkan kinerja organisasional (Collins \& Poras, 1997; Sako, 1998 dalam Tzafrir \& Gun, 2007). Oleh karena itu, trust menjadi sumber daya tak berwujud yang penting bagi organisasi yang mengikat para manajer dengan bawahan bawahan mereka. 
Trust dalam organisasi berkembang melalui proses pertukaran sosial, yang mana karyawan menginterpretasikan praktek, prosedur, dan tindakan manajerial, serta membalas organisasi berdasarkan itu (Whitener, 2001). Ketika manajemen menggunakan praktek yang secara prosedural adil akan mempengaruhi kepercayaan karyawan pada manajemen, sebab prosedur tersebut menunjukkan penghargaan atas hak dan martabat karyawan secara individual. Misal dengan menawarkan peluang promosi dan pelatihan yang memadai, menjadi sinyal bagi karyawan bahwa organisasinya menghargai mereka dan berupaya ekstra memenuhi kebutuhan organisasional dan personal mereka (Schneider \& Bowen, 1993). Menanggapi kebijaksanaan tersebut, kepercayaan karyawan pada organisasi dan manajer mereka cenderung meningkat, yang secara jangka panjang efektif mengarah pada kinerja organisasional. Sejumlah praktek manajemen SDM lainnya juga bisa menjelaskan hubungan trust dengan kinerja organisasional. Penilaian kinerja yang dipersepsikan akurat dan memuaskan, kompensasi yang mencerminkan keadilan dan berbasis kinerja, juga berpotensi meningkatkan kinerja. Keterkaitan semuanya semakin menguatkan kepercayaan karyawan pada atasan mereka.

\section{Komitmen Organisasional, Kepuasan Kerja, dan Trust}

Komitmen adalah kekuatan relatif dari identifikasi individu dengan organisasi dan keterlibatannya dalam organisasi. Pemenuhan kebutuhan sosioemosional seperti afiliasi dan dukungan emosional, akan menghasilkan sense of belonging (rasa memiliki) yang kuat pada organisasi. Meskipun hubungan karyawan dengan atasannya (supervisor dengan subordinate) memberikan kontribusi bagi peningkatan komitmen karyawan, namun kepercayaan pada organisasi lebih kuat hubungannya. Sebagaimana pendapat Eisenberger, Fasolo, and Davis-LaMastro (1990) dan sejumlah studi empiris lainnya, bahwa karyawan melibatkan diri secara afektif pada organisasi didasari persepsi bahwa organisasi committed dengan mereka.

Komitmen organisasional dipergunakan sebagai suatu konstruk untuk memahami perilaku karyawan. Komitmen terhadap organi- sasi merefleksikan kekuatan relatif proses pengidentifikasian individu mengenai keterlibatannya dalam suatu organisasi. Ada 3 (tiga) komponen dalam komitmen organisasional, yaitu : keyakinan dan kemampuan untuk menerima tujuan organisasi, kesediaan untuk menjadi bagian dari organisasi, dan keinginan untuk mempertahankan keanggotaan dalam organisasi.

Komitmen tersebut digambarkan sebagai suatu kontinum yang bergerak dari tingkat rendah, moderat, dan tinggi yang mana masing-masing mempunyai pengaruh positif dan negatif. Pada komitmen rendah, dampak negatifnya pada individu antara lain peningkatan karir dan promosi yang lambat hingga kondisi yang terburuk yaitu dikeluarkan dari organisasi atau melakukan usaha untuk menghambat tujuan organisasi. Pada tingkatan organisasi, rendahnya komitmen anggota terhadap organisasi dapat berdampak pada meningkatnya turnover dan absenteeism, rendahnya kualitas kerja dan loyalitas serta sering melakukan aktifitas yang menentang organisasi. Pada komitmen tinggi, dampak negatif pada individu, antara lain menghilangkan daya kreativitas, inovasi dan kesempatan berkarya, resisten terhadap perubahan, mengalami stres dan tekanan dalam lingkungan keluarga dan sosial, kurangnya solidaritas antar rekan sekerja, dan terbatasnya waktu untuk halhal di luar pekerjaan. Pada tingkat organisasi, tingginya komitmen berdampak negatif seperti pemanfaatan sumber daya yang tidak efektif, tidak pekanya organisasi terhadap perubahan, tidak fleksibel dan tidak mampu untuk beradaptasi.

Kepercayaan akan dukungan organisasional akan berhubungan dengan outcomes yang mempengaruhi organisasi secara keseluruhan, sedangkan kepercayaan akan dukungan atasan langsung akan berhubungan dengan outcomes yang mempengaruhi pemimpin dan kelompok kerjanya (Wayne, Shore, \& Liden, 1997). Diduga bahwa trust pada atasan didasarkan pada persepsi bawahan akan dukungan yang selama ini diterima dari atasan, sedangkan komitmen organisasi paling tepat diprediksi berdasarkan persepsi mengenai dukungan dari organisasi. Hal ini juga didukung oleh pendapat Eisenberger, Fasolo, and Davis-LaMastro (1990), yang menyatakan bahwa persepsi mengenai dukungan organisasi 
menciptakan perasaan berkewajiban untuk mendukung organisasi melalui sikap seperti komitmen.

Sejumlah penelitian sebelumnya berfokus pada hubungan antara kualitas pertukaran dengan sikap kerja dan perilaku supervisor dan bawahannya. Penelitiannya Liden and Graen (1980), Rosse and Kraut (1988), Scandura, Graen, and Novak (1986), Vecchio and Gobdel (1984), hasilnya menunjukkan bahwa dibandingkan dengan hubungan pertukaran kualitas rendah, hubungan pertukaran kualitas tinggi berhubungan dengan bimbingan dan dukungan supervisor yang lebih besar, turnover bawahan yang lebih rendah, serta kinerja dan kepuasan bawahan yang lebih tinggi (Wayne \& Ferris, 1990). Sedangkan hasil penelitiannya Crouch and Yetton (1988), menunjukkan bahwa kepercayaan pada atasan berhubungan dengan jumlah waktu dan tenaga yang dicurahkan pada pekerjaan serta berhubungan dengan sikap kerja (Wayne \& Ferris, 1990). Akhirnya, ditemukan 8 (delapan) studi yang secara konsisten mendukung adanya hubungan positif antara kepercayaan terhadap atasan dan komitmen organisasional, serta 7 (tujuh) studi yang menemukan hubungan positifnya dengan kepuasan kerja (Sherony \& Green, 2002).

\section{METODE PENELITIAN}

\section{Populasi dan Sampel Penelitian}

Analisis data pada penelitian ini merupakan proses mencari dan menyusun secara sistematis data yang diperoleh dari wawancara, catatan lapangan dan bahan- bahan lain sehingga dapat dengan mudah dipahami dan temuannya dapat diinformasikan kepada orang lain. Pelaksanaan analisisnya bersifat interaktif, yang mana proses dilakukan baik pada waktu pengumpulan data masih berlangsung, misalnya dalam bentuk perbandingan antar unit data, pengelompokan data, maupun saat pengumpulan data sudah berakhir, dalam penyusunan laporan yang melibatkan analisis tahap akhir.

Populasi penelitian ini adalah seluruh Bank di Jawa Tengah yang menawarkan produk syariah, baik berupa Bank Umum Syariah, BPR Syariah maupun Unit Usaha Syariah pada bank umum konvensional. Jumlah keseluruhan bank tersebut di Jawa Tengah pada tahun 2009 berdasarkan informasi dari Bank Indonesia yang dipublikasikan oleh Harian Republika adalah 25 bank baik milik pemerintah maupun swasta (4 Bank Umum Syariah, 9 Unit Usaha Syariah, 12 BPR Syariah).

Adapun yang dijadikan sampel penelitian adalah seluruh bank tersebut yang telah beroperasi di Jawa Tengah minimal 2 tahun. Kriteria tersebut dengan pertimbangan bahwa penelitian ini mengkaji praktek pengelolaan SDM, yang mana praktek tersebut merupakan proses panjang berkelanjutan dan saling terkait antara satu fungsi dengan fungsi lainnya dalam MSDM. Sehingga efektif tidaknya praktek yang dijalankan tidak bisa dengan segera dirasakan dampaknya terhadap kinerja organisasional melalui kinerja SDMnya.

Bank syariah yang memenuhi kriteria tersebut sejumlah 18 bank, yang terdiri dari 3 Bank Umum Syariah (BUS), 3 Unit Usaha Syariah (UUS), dan 12 Bank Pembiayaan Rakyat Syariah (BPRS). Pengumpulan data dari bulan Juni sampai dengan September 2010 dilakukan pada 14 bank syariah yang bersedia berpartisipasi. Responden dalam penelitian ini adalah 14 orang Manajer SDM/Direktur/Kepala Cabang, dan 70 orang karyawan.

\section{Definisi Operasional dan Pengukuran Variabel}

Kumpulan praktek manajemen SDM pada penelitian ini adalah berbagai bentuk kegiatan praktek SDM yang dijalankan oleh perbankan syariah. Dalam penelitian ini praktek MSDM yang diidentifikasi mendasarkan pada penelitian mengenai HR Practices yang dilakukan Verburg, Hartog, and Koopman (2007). Meliputi rekrutmen dan seleksi, formalisasi pekerjaan, pelatihan dan pengembangan, promosi jabatan, komunikasi, kompensasi, dan penilaian kinerja.

Pada penelitian ini, trust diartikan sebagai keinginan karyawan mencurahkan sumber daya bagi pihak manajemen berdasarkan pengharapan positifnya sebagai hasil interaksi positif keduanya selama ini. Instrumen yang digunakan terdiri dari 14 item untuk mengukur kepercayaan karyawan pada manajemen, yang dikembangkan oleh Tzafrir dan Dolan (2004). Instrumen tersebut ditanggapi oleh responden karyawan pada masing-masing bank.

Komitmen organisasional adalah tingkat seberapa besar karyawan mengidentifikasikan dirinya serta terlibat dengan perusahaan 
dan tidak ingin meninggalkannya. Variabel ini diukur menggunakan 9 item pertanyaan yang dikembangkan oleh Mowday, Steers, and Porter (1979). Instrumen tersebut ditanggapi oleh responden karyawan pada masing-masing bank.

Kepuasan kerja adalah sikap positif atau negatif yang dipegang oleh karyawan, yang mencakup kepuasan sosial, kepuasan ekstrinsik dan intrinsik mengenai pekerjaan mereka. Pengukuran variabel menggunakan 11 item pertanyaan yang dikembangkan oleh Schnake (1983). Semua item tersebut ditanggapi oleh responden karyawan pada masing-masing bank.

Kinerja Organisasional adalah sejauhmana sebuah bank syariah dalam hal ini manajer SDM dan atasan langsung karyawan menilai kemampuan karyawannya dalam pencapaian target pekerjaan. Selama ini, untuk mengevaluasi keefektifan praktek MSDM seringkali mendasarkan pada kinerja perusahaan yang diukur dengan variabel keuangan seperti ROA dan ROI serta pertumbuhan penjualan. Meski demikian, sejumlah pakar sebagaimana dinyatakan dalam artikelnya Colakoglu, Lepak and Hong (2006) yang menegaskan bahwa tidak ada cara yang tegas dalam mengukur kinerja perusahaan ketika menginvestigasi praktek-praktek MSDM tersebut. Apalagi praktek manajemen SDM merupakan proses panjang berkelanjutan dan saling terkait antara satu praktek dengan praktek lainnya. Sehingga efektif tidaknya praktek yang dijalankan tidak bisa memiliki hubungan kausal langsung dengan ROI misalnya. Oleh karena itu mengikuti pendapat Guest (1997), kinerja perusahaan diukur dengan indikator yang meliputi produktivitas, kualitas kerja, inovasi, kehadiran kerja, turnover, konflik, dan komplain nasabah. Selanjutnya, penjabaran indikator tersebut ke dalam item-item pertanyaan pada kuesioner dengan mempertimbangkan nilai-nilai kinerja Islam. Seluruh item tersebut ditanggapi oleh atasan langsung atau manajer SDM atau Direktur pada masing-masing bank, atas kinerja karyawan yang menjadi responden.

Jenis data yang digunakan pada penelitian ini meliputi data primer dan data sekunder. Data primer diperoleh langsung dari responden karyawan dan pihak manajemen. Responden karyawan memberikan data berupa tanggapan mengenai variabel praktek mana- jemen SDM, trust, kepuasan kerja, dan komitmen organisasional, serta identitas diri (usia, jenis kelamin, unit kerja, masa kerja, jabatan). Sedangkan Direktur/Manager SDM/Kepala Cabang memberikan data mengenai kebijakan dan praktek SDM yang dijalankan di bank masing-masing. Data sekunder diperoleh dari Bagian SDM/Bagian Umum, berupa profil perusahaan, struktur organisasi, jumlah dan status kepegawaian karyawan.

Analisis yang digunakan dalam penelitian ini adalah analisis deskriptif. Analisis kuantitatif digunakan untuk mengetahui nilai mean jawaban responden terhadap variabel praktek pengelolaan SDM, sikap kerja, dan kinerja. Hasil perhitungan statistik tersebut juga dianalisis secara deskriptif berdasarkan tanggapan terhadap pertanyaan terbuka dan kuesioner. Sementara analisis kualitatif digunakan untuk menilai berbagai kebijakan pada praktek pengelolaan SDM berdasarkan hasil wawancara mendalam dengan pihak manajemen.

Analisis data pada penelitian ini merupakan proses mencari dan menyusun secara sistematis data yang diperoleh dari wawancara, catatan lapangan dan isian kuesioner, sehingga dapat dengan mudah dipahami dan temuannya dapat diinformasikan kepada orang lain. Analisis dilakukan dengan deskriptif analitis. Informasi yang dikumpulkan di lapangan digunakan untuk membuat simpulan akhir, bukan untuk membuktikan hipotesis. Proses analisis data kualitatif dilakukan bersamaan dengan pengumpulan data, artinya analisis sudah dilakukan sejak awal, tidak sama dengan dengan analisis data dalam penelitian kuantitatif yang dilakukan setelah semua data terkumpul. Sedangkan data kuantitatif berdasarkan hasil pengisian kuesioner, diolah setelah proses survei berakhir, dan tidak ada lagi kuesioner yang bisa ditarik dari lapangan. Jadi terjadi proses interaktif dalam analisis data.

\section{HASIL ANALISIS \& PEMBAHASAN}

\section{Deskripsi Variabel}

\section{Trust}

Tabel 1 menunjukkan bahwa variabel trust terdiri dari 14 item pertanyaan. Tanggapan responden karyawan atas item-item tersebut menunjukkan tingkat kepercayaan mereka 
terhadap perusahaan dan pimpinan bank tempat mereka bekerja. Jawaban masih terkonsentrasi pada nilai tengah, yang diperjelas oleh besarnya nilai mean pada hampir semua item yang kurang dari 4. Hal ini menunjukkan bahwa sebagian besar karyawan masih belum sepenuhnya percaya akan perhatian perusahaan terhadap 'well being' mereka serta komitmen dalam memenuhi kebutuhan personal mereka di dalam perusahaan. Meskipun demikian bisa diartikan bahwa kepercayaan karyawan terhadap pimpinannya relatif lebih besar dibandingkan kepercayaan mereka terhadap perusahaan. Jika dikaitkan dengan hasil wawancara dengan pihak manajemen maupun sampel karyawan, bisa disimpulkan bahwa hal ini terkait dengan karakter organisasional dan praktek MSDM yang dijalankan. Bank syariah pada umumnya memiliki struktur organisasi yang 'flat', komunikasi formal maupun informal yang intens antara karyawan dengan pimpinan, kebijakan perusahaan dalam menyikapi gap antara kualitas input SDM dengan tuntutan pekerjaan, dan kekurang- sesuaian antara harapan akan nilai-nilai perusahaan dengan praktek yang dijalankan.

Struktur yang datar menjadikan kurangnya peluang bagi jenjang karir karyawan. Khususnya pada BPRS yang cakupannya lokal, dimana setiap bank hanya didukung oleh 1-3 kantor kas, sebagian besar bahkan belum memiliki kantor cabang pembantu maupun kantor kas. Dalam hal tingkat kompensasi juga mereka akui masih di bawah bank konvensional. Kemudian meski berlabel syariah, tapi kebijakan dalam praktek pengembangan karyawannya dinilai belum sepenuhnya Islami menurut persepsi karyawan. Sehingga muncul pemikiran mengenai sejauhmana kepentingan diri mereka diseimbangkan dengan kepentingan perusahaan. Di sisi lain dengan struktur yang flat, hubungan komunikasi antara bawahan dengan pimpinan berjalan cukup baik, tidak birokratis. Bahkan sejak proses seleksi hingga pelatihan, pimpinan sudah terlibat langsung dan berinteraksi dengan para karyawan. Ini cukup bisa menjelaskan kurang tingginya trust responden karyawan terhadap perusahaannya.

Tabel 1: Deskripsi Statistik Variabel Trust

\begin{tabular}{|c|c|c|c|c|c|c|c|c|}
\hline Item & 1 & 2 & 3 & 4 & 5 & Min & $\operatorname{Max}$ & Mean \\
\hline $\begin{array}{l}\text { Perusahaan memandang penting kebutuhan dan } \\
\text { keinginan karyawan }\end{array}$ & 4 & 10 & 14 & 49 & 2 & 1 & 5 & 3,37 \\
\hline $\begin{array}{l}\text { Atasan bisa diandalkan saat ada kesulitan } \\
\text { dengan pekerjaan }\end{array}$ & 0 & 6 & 14 & 40 & 10 & 2 & 5 & 3,77 \\
\hline $\begin{array}{l}\text { Perusahaan akan selalu menepati janji pada } \\
\text { karyawan }\end{array}$ & 0 & 2 & 16 & 44 & 8 & 2 & 5 & 3,83 \\
\hline $\begin{array}{l}\text { Perusahaan sungguh-sungguh memerhatikan } \\
\text { "kondisi baik" karyawan }\end{array}$ & 0 & 4 & 20 & 42 & 4 & 2 & 5 & 3,66 \\
\hline $\begin{array}{l}\text { Asalkan mengakui dan minta maaf, saya yakin } \\
\text { perusahaan memaafkan kesalahan saya }\end{array}$ & 0 & 2 & 18 & 46 & 4 & 2 & 5 & 3,74 \\
\hline $\begin{array}{l}\text { Tindakan dan perilaku atasan konsisten dengan } \\
\text { perkataannya }\end{array}$ & 4 & 4 & 20 & 34 & 8 & 1 & 5 & 3,54 \\
\hline $\begin{array}{l}\text { Atasan sukses menjalankan berbagai hal yang } \\
\text { dikerjakannya }\end{array}$ & 0 & 0 & 28 & 36 & 6 & 3 & 5 & 3,69 \\
\hline Hubungan atasan dengan bawahan hangat & 4 & 6 & 8 & 38 & 14 & 1 & 5 & 3,74 \\
\hline $\begin{array}{l}\text { Penggantian personil dilakukan dengan } \\
\text { mengorbankan karyawan lain }\end{array}$ & 2 & 10 & 18 & 28 & 12 & 1 & 5 & 3,54 \\
\hline $\begin{array}{l}\text { Atasan mengekspresikan kesan yang } \\
\text { sesungguhnya mengenai hal penting di } \\
\text { perusahaan }\end{array}$ & 0 & 0 & 16 & 50 & 4 & 3 & 5 & 3,83 \\
\hline Tindakan atasan konsisten dengan ucapannya & 4 & 2 & 20 & 42 & 2 & 1 & 5 & 3,51 \\
\hline $\begin{array}{l}\text { Atasan memiliki banyak pengetahuan mengenai } \\
\text { pekerjaannya }\end{array}$ & 0 & 0 & 2 & 54 & 14 & 3 & 5 & 4,17 \\
\hline Atasan terbuka dengan bawahan & 0 & 0 & 28 & 38 & 4 & 3 & 5 & 3,66 \\
\hline $\begin{array}{l}\text { Atasan tidak akan melakukan hal yang bisa } \\
\text { merugikan perusahaan }\end{array}$ & 0 & 2 & 14 & 44 & 10 & 2 & 5 & 3,89 \\
\hline
\end{tabular}

Sumber: Data primer yang telah diolah, 2010. 


\section{Rekrutmen dan Seleksi}

Tabel 2: Deskripsi Statistik Variabel Rekrutmen dan Seleksi

\begin{tabular}{lcccccccc}
\hline \multicolumn{1}{c}{ Item } & 1 & 2 & 3 & 4 & 5 & Min & Max & Mean \\
\hline $\begin{array}{l}\text { Perusahaan menjalankan proses rekrutmen } \\
\text { secara terbuka }\end{array}$ & 0 & 0 & 10 & 44 & 16 & 3 & 5 & 4,09 \\
$\begin{array}{l}\text { Saat seleksi, perusahaan mendefinisikan } \\
\text { pekerjaan dengan jelas }\end{array}$ & 0 & 2 & 18 & 42 & 8 & 2 & 5 & 3,80 \\
$\begin{array}{l}\text { Ketika ada peluang jabatan yang strategis, } \\
\text { perusahaan selalu berusaha memenuhinya dari } \\
\text { dalam daripada merekrut dari luar perusahaan }\end{array}$ & 0 & 2 & 12 & 42 & 14 & 2 & 5 & 3,97 \\
$\begin{array}{l}\text { Perusahaan menjalankan tahapan seleksi yang } \\
\text { akurat dan adil }\end{array}$ & 0 & 2 & 6 & 48 & 14 & 2 & 5 & 4,06 \\
$\begin{array}{l}\text { Dalam proses seleksi, perusahaan menguji } \\
\text { pengetahuan calon karyawan mengenai prinsip } \\
\text { operasionalisasi perbankan syariah dan produk } \\
\text { syariah }\end{array}$ & 2 & 0 & 8 & 40 & 20 & 1 & 5 & 4,09 \\
\hline
\end{tabular}

Sumber: Data primer yang telah diolah, 2010.

Sebagaimana nampak pada Tabel 2 bahwa variabel rekrutmen dan seleksi diukur menggunakan 5 item pertanyaan. Item mengenai keterbukaan proses rekrutmen, keakuratan tahapan seleksi, dan adanya uji pengetahuan mengenai prinsip operasionalisasi perbankan dan produk syariah, ditanggapi baik oleh sebagian besar responden. Hal ini didukung oleh besarnya nilai mean yang lebih dari 4 . Hasil wawancara di lapangan mendukung temuan tersebut. Semua bank syariah yang menjadi responden pada penelitian ini, pihak manajemennya menyatakan bahwa adanya peluang pekerjaan dipublikasikan secara terbuka, hanya media rekrutmennya saja yang berbedabeda. Kemudian saat seleksi, pengetahuan syariah Islam diujikan pada kandidat. Hanya metode serta tingkatan materinya saja yang berbeda pada masing-masing bank. Ada yang berupa tes tertulis dan ada juga yang menggali pengetahuan syariah dengan menggunakan wawancara. Sedangkan untuk item ke-2, mengenai pendefinisian pekerjaan dengan jelas, nilai rata-ratanya paling rendah diantara itemitem yang lain. Hal ini dikarenakan bank syariah sudah memiliki deskripsi pekerjaan yang detil untuk setiap jabatan, namun baru akan dijelaskan pada pelamar yang sudah dinyatakan diterima berdasarkan Surat Keputusan Direksi. Sedangkan uraian tugas, tanggung jawab, ataupun wewenang tersebut seringkali kurang sesuai dengan gambaran deskripsi pekerjaan pada saat seleksi.

\section{Formalisasi Pekerjaan}

Pada Tabel 3 dapat dilihat bahwa sebagian besar responden menyatakan tingkat kesetujuan yang tinggi mengenai formalisasi pekerjaan pada perusahaan/bank tempatnya bekerja. Nampak dari nilai rata-rata hitung yang sama dengan atau lebih besar dari 4 , dan sebaran jawaban yang terkonsentrasi pada skor 4 (setuju) dan 5 (sangat setuju). Sebagaimana lazimnya perusahaan pada industri perbankan, terkait aturan, kebijakan, pedoman dan prosedur kerja memang sudah distandarkan dan formal/tertulis. Sosialisasinyapun dilakukan secara berkelanjutan dengan memanfaatkan forum briefing pagi atau pertemuan rutin harian maupun mingguan. Sedangkan sebagian kecil responden yang kurang atau bahkan tidak setuju dengan keempat item pernyataan tersebut, menyatakan bahwa tanggapan tersebut didasarkan meskipun ada manual book-nya, tapi karyawan sejak bergabung hingga saat ini tidak mendapatkan buku pegangannya. Untuk mengetahui lebih detil atau ketika ada permasalahan terkait kebijakan atau prosedur pengoperasian, karyawan musti meminjamnya dulu di Bagian Umum. 
Tabel 3: Deskripsi Statistik Variabel Formalisasi Pekerjaan

\begin{tabular}{lcccccccc}
\hline \multicolumn{1}{c}{ Item } & 1 & 2 & 3 & 4 & 5 & Min & Max & Mean \\
\hline Aturan pendisiplinan karyawan secara tertulis & 0 & 0 & 12 & 46 & 12 & 3 & 5 & 4,0 \\
$\begin{array}{l}\text { Ada pedoman, kebijakan, peraturan, dan prosedur } \\
\text { kerja secara tertulis }\end{array}$ & 0 & 0 & 6 & 50 & 14 & 3 & 5 & 4,11 \\
Karyawan memiliki deskripsi pekerjaan yang akurat & 0 & 2 & 6 & 52 & 10 & 2 & 5 & 4,0 \\
Ada kontrak kerja antara karyawan dengan perusahaan & 0 & 2 & 6 & 48 & 14 & 2 & 5 & 4,06 \\
\hline
\end{tabular}

Sumber: Data primer yang telah diolah, 2010.

\section{Pelatihan dan Pengembangan}

Tabel 4: Deskripsi Statistik Variabel Pelatihan dan Pengembangan

\begin{tabular}{|c|c|c|c|c|c|c|c|c|}
\hline Item & 1 & 2 & 3 & 4 & 5 & Min & Max & Mean \\
\hline $\begin{array}{l}\text { Perusahaan mendesain dan mengembangkan metode, } \\
\text { teknik dan kriteria evaluasi pelatihan dengan baik }\end{array}$ & 0 & 0 & 20 & 40 & 10 & 3 & 5 & 3,86 \\
\hline $\begin{array}{l}\text { Perusahaan memberikan konseling mengenai } \\
\text { perencanaan karir karyawan }\end{array}$ & 2 & 2 & 22 & 38 & 6 & 1 & 5 & 3,63 \\
\hline Material pelatihan didesain dan dijalankan dengan baik & 0 & 0 & 22 & 38 & 10 & 3 & 5 & 3,83 \\
\hline $\begin{array}{l}\text { Perusahaan menganalisis kebutuhan pelatihan dengan } \\
\text { baik }\end{array}$ & 0 & 0 & 24 & 38 & 8 & 3 & 5 & 3,77 \\
\hline Program pelatihan terjadwal dan disosialisasikan & 0 & 0 & 20 & 44 & 6 & 3 & 5 & 3,80 \\
\hline $\begin{array}{l}\text { Ada kesesuaian antara materi, karyawan yang dilatih, } \\
\text { dan tuntutan pekerjaan }\end{array}$ & 0 & 0 & 10 & 54 & 6 & 3 & 5 & 3,94 \\
\hline $\begin{array}{l}\text { Alokasi waktu pelatihan dan frekuensi pelaksanaan } \\
\text { memenuhi kebutuhan karyawan }\end{array}$ & 0 & 0 & 24 & 40 & 6 & 3 & 5 & 3,74 \\
\hline
\end{tabular}

Sumber: Data primer yang telah diolah, 2010.

Berdasarkan Tabel 4. dapat disimpulkan bahwa sebagian besar responden menanggapi praktek pelatihan dan pengembangan belum dijalankan dengan optimal . Nilai rata-rata pada masing-masing variabel kurang dari 4 , dan sedikitnya $28,5 \%$ dari responden menyatakan kurang setuju jika perusahaan merencanakan dan menjalankan praktek pelatihan dengan baik. Item pernyataan mengenai kesesuaian antara materi pelatihan, trainee, dengan tuntutan pekerjaan, desain dan pelaksanaan material pelatihan, serta adanya metode, teknik dan kriteria evaluasi pelatihan, ditanggapi cukup positif oleh sebagian besar responden. Sebaliknya, item pernyataan mengenai alokasi waktu pelatihan dan frekuensi pelaksanaan dinilai belum sepenuhnya memenuhi kebutuhan karyawan. Tanggapan atas sejumlah item tersebut jika dikaitkan dengan hasil pertanyaan terbuka (pada kuesioner) dan wawancara dengan pihak manajemen, ada beberapa hal yang bisa menjadi penjelas. Sebagian besar bank syariah tidak menjalankan pelatihan secara on-site, melainkan mengikutsertakan perwakilan karyawan pada pelatihan bersama yang diselenggarakan pihak eksternal. Misal lembaga pendidikan tinggi, Asosiasi Bank Islam Indonesia (Asbisindo), atau pusat pelatihan perbankan milik swasta. Siapa saja karyawan yang dikirimkan sebagai trainee menyesuaikan dengan materi pelatihan yang akan diikuti. Pelaksanaan oleh lembaga profesional tersebut tentu saja dari sisi metode, teknik, dan materi pelatihan didesain serta dijalankan dengan baik. Namun dari sisi bank peserta, frekuensi dan waktu pelaksanaannya menjadi bergantung pada ada tidaknya penawaran pelatihan dari pihak eksternal tersebut. Begitupula kegiatan pelatihan tidak diprogram secara terstruktur pada setiap awal tahun. Di tengah proses operasional usaha ketika dipandang diperlukan pelatihan, barulah itu dilaksanakan berupa in-house training dengan trainer internal (biasanya direktur/pimpinan cabang). 


\section{Promosi Jabatan}

Tabel 5 menunjukkan bahwa variabel promosi jabatan diukur oleh 2 (dua) item pertanyaan. Semula ada 3 (tiga) item, tapi salah satu item tidak bisa dianalisis lebih lanjut karena tidak reliabel. Proses promosi jabatan dan dasar penetapannya masih belum dipersepsikan tinggi oleh sebagian karyawan, yang ditunjukkan dengan rata-rata penilaian yang kurang dari 4. Adanya peluang jabatan selama ini memang dikomunikasikan dan ditawarkan ke karyawan yang ada, namun untuk posisi yang tergolong strategis kadang perusahaan melakukan rekrutmen eksternal (karyawan ex bank lain, biasanya dari bank konvensional). Dasar penetapan promosinya pun dipersepsikan masih belum jelas dan belum bisa sepenuhnya diterima secara positif oleh karyawan. Hal ini terkait dengan item pada variabel pelatihan dan pengembangan (Tabel 4). Bahwa pemberian konseling mengenai perencanaan karir karyawan masih dinilai kurang oleh sebagian responden, sehingga karyawan pun kurang memahami peluang dan kriteria promosi jabatan.

\section{Komunikasi}

Variabel komunikasi pada penelitian ini diukur menggunakan 7 (tujuh) item pertanyaan, baik menyangkut komunikasi formal maupun informal, antara bawahan dengan pimpinan mau- pun diantara rekan kerja, serta baik berkelompok maupun personal dengan atasan.. Tanggapan responden terhadap keseluruhan item tersebut dengan nilai mean berkisar 3,84 hingga 4,03. Jumlah SDM yang relatif sedikit dan struktur organisasi yang flat mendukung proses komunikasi 2 arah yang lebih intens dan tidak terlalu birokratis. Pertemuan rutin seperti briefing dan doa pagi yang rutin dilakukan, menjadi sarana mengkomunikasikan kebijakan, berbagi pengalaman, dan penyelesaian konflik terkait dengan pekerjaan. Kegiatan informal seperti pengajian yang rata-rata diadakan seminggu sekali, cukup efektif dalam meningkatkan hubungan interpersonal baik diantara karyawan maupun dengan pimpinan. Sedangkan serikat karyawan menurut persepsi responden bukanlah serikat kerja sebagaimana lazim ditemui di industri manufaktur. Melainkan pertemuan diantara karyawan baik di kantor cabang maupun dengan seluruh karyawan di kantor cabang pembantu dan kantor kas, yang biasanya diadakan sebulan sekali. Pola komunikasi terjadi secara informal yang juga menghadirkan pihak manajemen. Oleh karena itulah sebagian responden mempersepsikan keberadaan serikat karyawan, sedangkan sebagian yang lain mempersepsikan sebaliknya. Fenomena tersebut menunjukkan bahwa meskipun ada tapi kegiatan informal karyawan belum diimplementasikan dengan baik.

Tabel 5: Deskripsi Statistik Variabel Promosi Jabatan

\begin{tabular}{lcccccccc}
\hline \multicolumn{1}{c}{ Item } & 1 & 2 & 3 & 4 & 5 & Min & Max & Mean \\
\hline Proses promosi jabatan dijalankan dengan fair & 0 & 0 & 18 & 48 & 4 & 3 & 5 & 3,80 \\
Dasar penetapan promosi jelas dan dapat diterima & 0 & 2 & 24 & 40 & 4 & 2 & 5 & 3,66 \\
\hline
\end{tabular}

Sumber: Data primer yang telah diolah, 2010.

Tabel 6: Deskripsi Statistik Variabel Komunikasi

\begin{tabular}{lcccccccc}
\hline \multicolumn{1}{c}{ Item } & 1 & 2 & 3 & 4 & 5 & Min & Max & Mean \\
\hline Komunikasi antara karyawan dengan pimpinan & 0 & 0 & 12 & 50 & 8 & 3 & 5 & 3,94 \\
Atasan bersedia menerima masukan dari karyawan & 0 & 2 & 12 & 44 & 12 & 2 & 5 & 3,94 \\
Pertemuan informal antara karyawan dengan atasan & 0 & 0 & 14 & 48 & 8 & 3 & 5 & 3,91 \\
Perbedaan status & 0 & 0 & 13 & 55 & 2 & 3 & 5 & 3,84 \\
$\begin{array}{l}\text { Perusahaan mengkomunikasikan kebijakan, pedoman, } \\
\text { maupun aturan baru }\end{array}$ & 0 & 0 & 10 & 54 & 6 & 3 & 5 & 3,94 \\
Ada serikat karyawan & 2 & 12 & 20 & 36 & 0 & 1 & 4 & 3,29 \\
Ada kegiatan informal seperti pengajian, olahraga dll. & 2 & 0 & 8 & 44 & 16 & 1 & 5 & 4,03 \\
\hline
\end{tabular}

Sumber: Data primer yang telah diolah, 2010. 


\section{Kompensasi}

Tabel 7: Deskripsi Statistik Variabel Kompensasi

\begin{tabular}{lcccccccc}
\hline \multicolumn{1}{c}{ Item } & 1 & 2 & 3 & 4 & 5 & Min & Max & Mean \\
\hline Peningkatan gaji/bonus didasarkan kinerja & 2 & 0 & 10 & 44 & 14 & 1 & 5 & 3,97 \\
$\begin{array}{l}\text { Besaran kompensasi ditetapkan secara adil } \\
\begin{array}{l}\text { Jenis dan besarnya kompensasi kompetitif } \\
\text { dibanding pekerjaan sejenis di bank lain }\end{array}\end{array}$ & 0 & 2 & 18 & 38 & 12 & 2 & 5 & 3,86 \\
\hline
\end{tabular}

Sumber: Data primer yang telah diolah, 2010.

Sebagaimana ditampilkan pada Tabel 7, bahwa variabel kompensasi diukur menggunakan 3 (tiga) item pertanyaan. Ratarata jawaban pada masing-masing item berkisar dari 3,60 hingga 3,97. Sebagian besar responden mengakui bahwa besaran kompensasi yang ditetapkan perusahaan adil dan peningkatannya didasarkan pada kinerja masing-masing karyawan. Namun, sebagian responden menanggapi bahwa jenis dan besaran kompensasi yang mereka terima tidak kompetitif jika dibandingkan dengan jenis pekerjaan yang sama di bank lain. Hal ini diakui oleh pihak manajemen bahwa memang ada keterbatasan perusahaan dalam pemberian paket kompensasi bagi karyawannya jika dibandingkan dengan bank lain, terutama bank konvensional. Adapun penilaian positif responden terhadap item tersebut (skor 4 dan 5), dilatarbelakangi oleh banknya yang berstatus BUS atau UUS, yang mana standar kompensasinya menyesuaikan dengan bank konvensionalnya. Oleh karenanya dapat disimpulkan bahwa kebijakan dalam praktek kompensasi pada rata-rata bank syariah lebih menekankan pada keadilan internal daripada keadilan eksternalnya.

\section{Penilaian Kinerja}

Variabel penilaian kinerja diukur menggunakan 6 (enam) item pertanyaan terkait dengan standar penilaian, proses, frekuensi, umpan balik, hingga tujuan penilaian. Sebagian besar responden mempersepsikan penilaian berdasarkan kinerja riil karyawan, fair dan akurat, dan standar evaluasinya jelas. Bahkan item terkait dengan pelaksanaan penilaian yang dilakukan secara teratur/periodik pun meraih tingkat kesetujuan tertinggi diantara item-item lainnya. Namun, meskipun dilaksanakan secara teratur, sebagian besar karyawan tidak yakin bila penilaian tersebut juga ditujukan untuk pengembangan diri mereka. Misal sebagai dasar promosi jabatan, atau dasar penetapan kebutuhan pelatihan. Penilaian kinerja yang mereka jalani selama ini lebih dipersepsikan untuk kepentingan administratif.

Tabel 8: Deskripsi Statistik Variabel Penilaian Kinerja

\begin{tabular}{|c|c|c|c|c|c|c|c|c|}
\hline Item & 1 & 2 & 3 & 4 & 5 & Min & Max & Mean \\
\hline $\begin{array}{l}\text { Umpan balik penilaian kinerja secara teratur } \\
\text { dan konstruktif }\end{array}$ & 0 & 2 & 16 & 46 & 6 & 2 & 5 & 3,8 \\
\hline Penilaian kinerja fair dan akurat & 0 & 2 & 18 & 44 & 6 & 2 & 5 & 3,77 \\
\hline $\begin{array}{l}\text { Standard/ukuran evaluasi jelas dan dapat } \\
\text { diandalkan }\end{array}$ & 0 & 0 & 14 & 54 & 2 & 3 & 5 & 3,83 \\
\hline Berdasarkan kinerja karyawan & 0 & 0 & 10 & 58 & 2 & 3 & 5 & 3,89 \\
\hline Dilakukan secara teratur tiap periode & 0 & 0 & 6 & 64 & 0 & 3 & 4 & 3,91 \\
\hline $\begin{array}{l}\text { Penilaian bukan sekedar untuk kepentingan } \\
\text { administratif, tapi juga pengembangan } \\
\text { karyawan }\end{array}$ & 0 & 10 & 44 & 10 & 6 & 2 & 5 & 3,17 \\
\hline
\end{tabular}

Sumber: Data primer yang telah diolah, 2010. 


\section{Komitmen Organisasional}

Tabel 9: Deskripsi Statistik Variabel Komitmen Organisasional

\begin{tabular}{|c|c|c|c|c|c|c|c|c|}
\hline Item & 1 & 2 & 3 & 4 & 5 & Min & Max & Mean \\
\hline $\begin{array}{l}\text { Berusaha keras melebihi yang diharapkan guna } \\
\text { keberhasilan perusahaan }\end{array}$ & 0 & 0 & 10 & 40 & 20 & 3 & 5 & 4,14 \\
\hline $\begin{array}{l}\text { Membanggakan perusahaan kepada orang lain } \\
\text { sebagai tempat bekerja yang baik }\end{array}$ & 0 & 0 & 6 & 52 & 12 & 3 & 5 & 4,09 \\
\hline Akan menerima hampir semua jenis tugas & 0 & 4 & 30 & 28 & 8 & 2 & 5 & 3,57 \\
\hline $\begin{array}{l}\text { Ada kesamaan antara nilai-nilai saya dengan } \\
\text { perusahaan }\end{array}$ & 0 & 0 & 12 & 56 & 2 & 3 & 5 & 3,86 \\
\hline $\begin{array}{l}\text { Bangga memberitahu orang lain bahwa menjadi } \\
\text { bagian dari perusahaan }\end{array}$ & 0 & 0 & 4 & 52 & 14 & 3 & 5 & 4,14 \\
\hline $\begin{array}{l}\text { Perusahaan memberi inspirasi terbaik dalam } \\
\text { mencapai kinerja }\end{array}$ & 0 & 0 & 18 & 42 & 10 & 3 & 5 & 3,89 \\
\hline Sangat senang telah memilih sebagai tempat bekerja & 0 & 0 & 8 & 56 & 6 & 3 & 5 & 3,97 \\
\hline $\begin{array}{l}\text { Benar-benar perduli terhadap kelangsungan hidup } \\
\text { bank }\end{array}$ & 0 & 0 & 0 & 54 & 16 & 4 & 5 & 4,23 \\
\hline $\begin{array}{l}\text { Bank ini menjadi pilihan terbaik diantara perusahaan } \\
\text { yang mungkin sebagai tempat bekerja saya }\end{array}$ & 0 & 0 & 22 & 40 & 8 & 3 & 5 & 3,80 \\
\hline
\end{tabular}

Sumber: Data primer yang telah diolah, 2010.

Variabel komitmen organisasional diukur menggunakan 9 (sembilan) item pertanyaan, untuk menunjukkan seberapa besar kekuatan relatif dari identifikasi individu dengan perusahaan dan keterlibatannya dalam perusahaan. Tabel 9. menunjukkan bahwa sebagian besar responden menyatakan berusaha keras melebihi yang diharapkan guna keberhasilan perusahaan, membanggakan perusahaannya sebagai tempat bekerja yang baik dan membanggakannya kepada orang lain, serta perduli terhadap kelangsungan hidupnya. Nilai rata-rata untuk masing-masing item tersebut lebih dari 4, yaitu berkisar antara 4,09 hingga 4,23. Namun, untuk item mengenai kesesuaian dengan nilai-nilai perusahaan serta kemampuan perusahaan dalam menginspirasi karyawan, nilai rata-rata hitungnya lebih rendah, kurang dari 4. Begitupula untuk item yang menunjukkan keyakinan responden bahwa perusahaan menjadi pilihan terbaik diantara perusahaan yang mungkin sebagai tempat bekerja, memiliki nilai rata-rata 3,8 Hal ini dapat diartikan bahwa sebagian besar responden sejauh ini memiliki kesediaan untuk menjadi bagian perusahaan dan berupaya memajukan perusahaan, namun tidak sepenuhnya merasakan kesesuaian dengan nilai-nilai organisasional yang ada. Lebih dari itu, temuan di lapangan tersebut menunjukkan adanya kecenderungan untuk meninggalkan perusahaan ketika ada peluang di tempat lain.

Ada 3 (tiga) komponen dalam komitmen organisasional, yaitu: keyakinan dan kemampuan untuk menerima tujuan organisasi, kesediaan untuk menjadi bagian dari organisasi, dan keinginan untuk mempertahankan keanggotaan dalam organisasi. Tanggapan responden pada variabel ini menunjukkan bahwa karyawan hanya memenuhi komponen pertama, tapi tidak ke-2 dan ke-3. Jika dikaitkan dengan pernyataan pihak manajemen sejumlah bank responden, diakui bahwa perusahaan seringkali hanya menjadi 'batu loncatan' bagi karyawannya. Dapat disimpulkan bahwa karyawan bank syariah yang menjadi responden pada penelitian ini memiliki jenis komitmen continuance, dimana kekuatan dari keinginan individu untuk terus bekerja di perusahaannya sekarang lebih dikarenakan kebutuhan mereka untuk tinggal. 


\section{Kepuasan Kerja}

Tabel 10: Deskripsi Statistik Variabel Kepuasan Kerja

\begin{tabular}{lcccccccc}
\hline \multicolumn{1}{c}{ Item } & 1 & 2 & 3 & 4 & 5 & Min & Max & Mean \\
\hline Persahabatan dengan rekan kerja & 0 & 2 & 8 & 54 & 6 & 2 & 5 & 3,91 \\
Penghargaan dari rekan kerja & 0 & 2 & 10 & 58 & 0 & 2 & 4 & 3,80 \\
Perlakuan dari rekan kerja & 0 & 0 & 14 & 48 & 8 & 3 & 5 & 3,91 \\
Jaminan keberlangsungan kerja & 0 & 4 & 14 & 50 & 2 & 2 & 5 & 3,71 \\
Besar tunjangan & 2 & 0 & 42 & 26 & 0 & 1 & 4 & 3,31 \\
Kebebasan menjalankan pekerjaan & 0 & 0 & 12 & 58 & 0 & 3 & 4 & 3,83 \\
Besar gaji & 2 & 0 & 36 & 32 & 0 & 1 & 4 & 3,40 \\
Kesempatan melakukan pekerjaan yang membanggakan & 0 & 0 & 12 & 56 & 2 & 3 & 5 & 3,86 \\
Kesempatan belajar hal baru & 0 & 0 & 12 & 52 & 6 & 3 & 5 & 3,91 \\
Kesempatan melakukan hal berarti & 0 & 0 & 12 & 54 & 4 & 3 & 5 & 3,89 \\
Kesempatan ikut dalam pembuatan keputusan & 0 & 6 & 16 & 48 & 0 & 2 & 4 & 3,60 \\
\hline Sum
\end{tabular}

Sumber: Data primer yang telah diolah, 2010.

Variabel kepuasan kerja diukur menggunakan 11 (sebelas) item pertanyaan. Kepuasan terkait kualitas hubungan dengan rekan kerja, kebebasan menjalankan pekerjaan, melakukan pekerjaan yang membanggakan, dan kesempatan mempelajari hal-hal baru dan berarti, memiliki nilai rata-rata kepuasan kerja yang relatif lebih baik dibandingkan item yang lain pada variabel ini. Sedangkan kepuasan kerja yang terendah adalah kepuasan terhadap besarnya tunjangan dan gaji, dengan nilai jawaban minimum 1 (sangat tidak setuju). Temuan ini dapat dijelaskan dengan mengkait- kan jawaban responden terhadap variabel kompensasi dan komunikasi, sebagaimana nampak pada Tabel 6. dan 7. Responden mempersepsikan bahwa kualitas dan kuantitas komunikasi pada perusahaan cukup baik. Hal ini meningkatkan kualitas hubungan interpersonal yang akhirnya mempengaruhi kepuasan kerja karyawan. Sebaliknya, sebagian responden mempersepsikan kurang kompetitifnya jenis dan besaran kompensasi yang ditetapkan perusahaan, yang mempengaruhi rendahnya kepuasan kerja mereka.

\section{Kinerja}

Tabel 11: Deskripsi Statistik Variabel Kinerja

\begin{tabular}{|c|c|c|c|c|c|c|c|c|}
\hline Item & 1 & 2 & 3 & 4 & 5 & Min & $\operatorname{Max}$ & Mean \\
\hline Melakukan tugas dengan baik & 0 & 0 & 0 & 64 & 6 & 4 & 5 & 4,09 \\
\hline $\begin{array}{l}\text { Berusaha menemukan alternatif terbaik dalam memberikan } \\
\text { layanan }\end{array}$ & 0 & 0 & 4 & 60 & 6 & 3 & 5 & 4,03 \\
\hline Luwes dalam melayani kebutuhan/ keinginan nasabah & 0 & 0 & 4 & 58 & 8 & 3 & 5 & 4,06 \\
\hline Memahami peraturan perusahaan & 0 & 0 & 0 & 70 & 0 & 4 & 4 & 4,00 \\
\hline Tulus dan istiqamah & 0 & 0 & 2 & 58 & 10 & 3 & 5 & 4,11 \\
\hline Bisa bekerjasama & 0 & 0 & 2 & 60 & 8 & 3 & 5 & 4,09 \\
\hline Mampu menjelaskan produk/jasa syariah & 0 & 0 & 4 & 64 & 2 & 3 & 5 & 3,97 \\
\hline Mendukung budaya kerja etis & 0 & 0 & 0 & 64 & 6 & 4 & 5 & 4,09 \\
\hline $\begin{array}{l}\text { Memahami pengetahuan syariah dengan baik dan } \\
\text { menerapkannya }\end{array}$ & 0 & 0 & 2 & 68 & 0 & 3 & 4 & 3,97 \\
\hline Berpegang teguh pada kebenaran, kejujuran, dan amanah & 0 & 0 & 0 & 58 & 12 & 4 & 5 & 4,17 \\
\hline Mau melakukan usaha ekstra dalam menyelesaikan pekerjaan & 0 & 0 & 6 & 54 & 10 & 3 & 5 & 4,06 \\
\hline $\begin{array}{l}\text { Senantiasa menjaga sikap dan perkataan agar terhindar dari } \\
\text { perselisihan di tempat kerja }\end{array}$ & 0 & 2 & 2 & 58 & 8 & 2 & 5 & 4,03 \\
\hline
\end{tabular}

Sumber: Data primer yang telah diolah, 2010. 
Variabel kinerja diukur menggunakan 12 item pertanyaan, yang dijawab oleh pimpinan bank atau bagian SDI `menanggapi kinerja karyawan yang menjadi responden pada penelitian ini. Sebagian besar bank syariah menilai positif kinerja SDMnya. Melakukan tugas dengan baik, melayani kebutuhan nasabah, memahami aturan perusahaan, tulus dan istiqamah, bisa bekerjasama, mendukung budaya kerja etis, jujur dan amanah, mau berupaya ekstra dalam menyelesaikan pekerjaan, dan menjaga sikap serta perkataan. Kesemuanya mendapatkan nilai rata-rata 4 atau lebih. Namun pihak manajemen mengakui bahwa dalam hal kemampuan karyawan memahami pengetahuan syariah serta menjelaskan produk syariah ke nasabah, masih lebih rendah. Jika dikaitkan dengan sejumlah praktek pengelolaan SDM yang dijalankan perusahaan, kinerja yang demikian bisa dipahami. Sebagaimana telah diuraikan sebelumnya, bahwa input karyawan diakui perusahaan masih belum memadai pemahamannya mengenai perbankan syariah. Pada proses sejak rekrutmen hingga seleksi seringkali menemui ketidaksesuaian antara kapabilitas kandidat dengan kompetensi yang musti dipenuhi SDM di perbankan syariah. Disinilah peran strategis praktek pelatihan dalam mengatasi gap tersebut. Hanya saja realisasinya menunjukkan bahwa tingkat kesetujuan karyawan responden terhadap alokasi waktu pelatihan dan frekuensi pelaksanaannya belum memenuhi kebutuhan karyawan. Baik pelatihan yang diselenggarakan sendiri maupun oleh pihak eksternal, evaluasi pasca pelatihan pun belum secara optimal dilakukan. Kalaupun ada, belum terpola dengan baik pada sebagian besar bank responden.

\section{Analisis Kualitatif}

\section{Rekrutmen dan Seleksi}

Semua bank responden melakukan proses rekrutmen secara terbuka. Setiap bank memiliki pertimbangan sendiri terkait penggunaan media rekrutmennya. Pada umumnya bank syariah memiliki kerjasama dengan lembaga pendidikan tinggi atau menengah. Bentuk kerjasamanya antara lain berupa info lowongan kerja di media informasi kampus, rekomendasi lulusan potensial oleh pimpinan lembaga, maupun menjadi pembicara tamu pada forum ilmiah di kampus. Diharapkan bank bisa memiliki pengetahuan yang lebih memadai mengenai kualitas lulusan melalui indikator kurikulum yang digunakan. Hal ini didorong oleh adanya keterbatasan input sumber daya manusia yang menguasai pengetahuan syariah dan prinsip operasionalisasi perbankan syariah. Pada BPRS yang beroperasi dalam lingkup lokal, umumnya melakukan rekrutmen bekerjasama dengan lembaga pendidikan setempat/lokal. Baik melalui job posting di papan pengumuman kampus atau lembaga pendidikan, maupun menawarkan pada lulusan yang pernah magang di bank yang bersangkutan. Beberapa BPRS juga melakukan iklan di koran, pengumuman di kantor pos, dan rekomendasi karyawan. Sedangkan bank syariah yang berupa bank umum dan UUS yang cakupan operasinya lebih luas, bekerjasama dengan perguruan tinggi nasional, serta menggunakan media surat kabar yang jangkauan publikasinya lebih luas.

Terkait penggunaan sumber rekrutmen, ada perbedaan antara BUS dan UUS dengan BPRS. Pada BUS (yang merupakan pengembangan bank konvensional) dan UUS, sebagian SDM merupakan hasil rekrutmen dari karyawan di bank konvensionalnya. Pada wawancara, manajemen mengemukakan bahwa meskipun dari sisi pengetahuan syariah belum cukup memadai, namun setidaknya mereka sudah memiliki pengalaman dan kecakapan teknis terkait operasionalisasi perbankan. Kemudian pada posisi eksekutif, bank tersebut terkadang merekrut manajer dari bank konvensional. Sebagaimana dinyatakan oleh pimpinan bank umum syariah:

“...Nah, kenapa kita mau ambil eksekutif dari bank konvensional, karena dia sudah menguasai dulu syarat yang pertama, kemampuan teknis operasional bank sudah menguasai, baru dimasuki pengetahuan syariahnya".

Pada umumnya metode seleksi yang digunakan bank syariah responden adalah sama. Meliputi seleksi administratif, tes tertulis, psikotes, dan wawancara, dengan sistem gugur. Perbedaannya lebih pada jumlah tahapan serta materi yang diujikan. Umumnya metode wawancara hanya satu tahap, namun pada BUS metode seleksi tersebut dijalankan beberapa tahap dimana ada initial interview 
dan lanjutan. Kemudian materi tes tertulisnya ada yang hanya menguji pengetahuan ilmu ekonomi secara umum, namun sebagian besar bank juga menguji pengetahuan mengenai dasar keislaman, pengetahuan perbankan umum dan syariah. BPRS yang materi tesnya hanya menguji pengetahuan umum, menyatakan:

"Untuk mendapatkan pelamar yang qualified saja susah, apalagi kalau diuji juga pengetahuan syariahnya. Biasanya mereka kurang memahami itu, akhirnya malah kita sendiri yang kesulitan menentukan pelamar yang layak diterima".

Ketika hal itu menjadi keterbatasan, setidaknya pihak manajemen kemudian berusaha menggali nilai-nilai personal pada saat wawancara dengan pimpinan. Value personal yang mendukung penerapan budaya kerja Islami yang sesuai dengan nilai-nilai perusahaan. Inilah yang membedakan praktek seleksi antara bank syariah dengan bank konvensional. Meskipun pada akhirnya dalam menentukan diterima tidaknya kandidat, pertimbangan utamanya tidak selalu dari sisi ke-Islamannya namun lebih kepada penguasaan kompetensi teknis di bidang pekerjaan yang akan dijalani.

Praktek rekrutmen dan seleksi pada bank syariah bukannya tanpa kendala. Hampir semua bank responden menyatakan kurang tersedianya input SDM yang memiliki pengetahuan memadai mengenai perbankan syariah. Oleh karenanya pada bank syariah tertentu seperti BUS, kandidat yang diterima masih berstatus calon pegawai (capeg). Tujuannya untuk melihat kesesuaian antara hasil tes saat seleksi dan psikometri dengan kemampuan hard skill-nya, dan apakah karyawan yang bersangkutan bisa dikembangkan atau tidak. Kesulitan merekrut calon karyawan yang sesuai dengan kebutuhan perusahaan, dikemukakan oleh sebagian besar bank responden, sebagaimana dinyatakan oleh beberapa pimpinan BPRS berikut:

“...seringkali tidak match/tidak qualified sedangkan kompensasi belum bisa mengejar bank konvensional. Karyawan baru pun seringkali hanya menjadikan bank ini sebagai 'batu loncatan"”.
"Dari sisi SDM, beda dengan bank besar yang tidak lagi melihat siapa yang melayaninya (khususnya yang simpanan). Jadi kemampuan karyawan untuk penetrasi pasar menjadi penting. Karyawan musti punya network. Kuncinya ada di rekrutmen dan seleksi, untuk memastikan apakah calon karyawan punya potensi network dan kemampuan membangun jaringan sosial yang tinggi”.

\section{Formalisasi Pekerjaan}

Sebagaimana umumnya organisasi dengan struktur organisasi dan sistem kerja yang mapan, semua bank responden telah memiliki aturan pendisiplinan karyawan, pedoman, kebijakan, peraturan dan prosedur kerja tertulis, deskripsi pekerjaan dan kontrak kerja antara karyawan dengan perusahaan. Begitupula terkait dengan hubungan pemekerjaan antara bank dengan karyawan kontrak, sudah ada formalisasi kebijakannya. Aturan tertulis menyesuaikan peraturan pendisiplinan dari Departemen Tenaga Kerja, sedangkan pedoman kebijakan, peraturan dan prosedur kerja disusun dan disahkan dengan Surat Keputusan Direksi.

Aturan pendisiplinan, pedoman dan prosedur kerja sudah diformalisasikan, namun karyawan tidak mendapatkan copy fisiknya. Baru ketika ada permasalahan atau kebutuhan untuk mengetahui secara detil, karyawan bisa meminjam buku manual yang disimpan oleh bagian umum. Begitupula mengenai deskripsi pekerjaan pada sejumlah bank responden, yang meskipun sudah ada namun hanya disampaikan secara verbal lisan. Sebagaimana pernyataan dari beberapa manajer yang dirangkum dalam pernyataan berikut:

"Ada KKB (Kesepakatan Kerja Bersama) mengenai aturan pendisiplinan karyawan, kebijakan, peraturan, prosedur kerja, dan deskripsi pekerjaan. Tapi karyawan tidak diberi orang per orang".

Meski demikian, kekurangan tersebut dinilai pihak manajemen masih bisa diatasi dengan memanfaatkan sarana komunikasi formal maupun informal yang secara rutin diadakan. Misal, briefing pagi rutin antara pimpinan dengan para bawahannya menjadi media sosialisasi kebijakan, aturan, maupun prosedur 
kerja baru. Sehingga informasi yang dibutuhkan guna mendukung efektifitas pekerjaan bisa terus dan segera di-update.

\section{Pelatihan dan Pengembangan}

Pada umumnya bank responden menyatakan bahwa mereka menganggarkan biaya pelatihan karyawan sebesar 5\% (BUS 5\%-10\%) dari biaya tenaga kerja tahun sebelumnya, sebagaimana ketentuan dari Bank Indonesia. Hampir semua pimpinan bank menyatakan pentingnya kegiatan pelatihan bagi karyawan di bank syariah. Sebagaimana pernyataan salah seorang direktur bank syariah berikut:

"Upgrading skill dan knowledge pegawai perlu terus dilakukan seiring dengan tuntutan pelayanan maupun kompetisi dalam industri perbankan sehingga mampu melayani seluruh nasabah yang berlandaskan pada pencapaian nilai-nilai mardlotillah serta menjadikan lembaga sebagai rahmatan lil alamin".

Meskipun demikian waktu pelatihan, frekuensi, serta kebutuhan pelatihan apa yang akan diadakan selama 1 tahun ke depan belum dianalisis dan direncanakan pada awal tahun anggaran. Juga ada perbedaan berdasarkan jenis bank syariahnya. Pada BUS dan UUS, pelatihan untuk karyawan level manajerial dan pelatihan dasar terkait kualitas pelayanan dan pengetahuan produk misalnya, dilakukan secara terpusat di Jakarta. Adapun ketika selama tahun berjalan dirasakan ada keahlian atau pengetahuan spesifik yang dibutuhkan seiring dinamika cabang, barulah pelatihan tersebut dilaksanakan dengan metode in-house. Pada BPRS, perusahaan tidak mengadakan pelatihan sendiri, melainkan mengikutsertakan karyawannya pada pelatihan yang diadakan pihak eksternal, seperti Asosiasi Bank Islam Indonesia, lembaga pendidikan perbankan, atau perguruan tinggi setempat. Sedangkan peningkatan keahlian dan pengetahuan spesifik dilakukan berupa oleh pimpinan. Adanya ketergantungan pada pihak eksternal tersebut menyebabkan frekuensi pelaksanaan, kebutuhan pelatihan dan kesempatan karyawan mengikuti pelatihan menjadi terbatas. Beberapa bank mengidentifikasi kebutuhan pelatihan karyawan secara individual, yang terkadang dicantumkan pada lembar hasil penilaian kinerja mereka.
Namun apakah itu dilakukan atau tidak tetap saja bergantung pada ada tidaknya penawaran pelatihan oleh pihak eksternal ataupun kemampuan pimpinan memberikan pelatihan internal. Berikut pernyataan dari pimpinan bank responden:

"Faktor pendorong pelatihan pada dasarnya bisa dari atas, bisa juga dari bawah. Hanya memang yang nge-drive manajemen. Di bagian akhir form PA (penilaian kinerja) ada rekomendasi penilai (dirut) mengenai kebutuhan pelatihan ke depan. Misal, seorang AO Lending yang nantinya akan dipromosikan sebagai koordinator kantor kas, membutuhkan pelatihan building team. Sehingga nanti kalau ada peluang pelatihan itu, yang bersangkutan diprioritaskan dikirim".

Terkait evaluasi pelatihan, masingmasing bank responden memaknainya secara berbeda. Dari sisi sistem, belum ada aturan atau prosedur baku mengenai hal tersebut. Sehingga proses yang terjadi di masing-masing bank sangat dipengaruhi inisiatif dan komitmen pimpinan akan kompleksitas dan kontinuitas praktek yang dijalankan. Bahkan beberapa diantaranya dengan tegas menyatakan ketiadaan evaluasi pasca pelatihan, baik evaluasi terhadap peserta pelatihan maupun evaluasi dari sisi pelaksanaannya. Berikut beberapa pernyataan informan yang menyatakan melakukan evaluasi:

"Evaluasi pelatihan ada tapi belum terpola dengan baik. Karyawan yang mendapatkan pelatihan sekedar kami minta mengumpulkan modul-modulnya supaya bisa dibaca yang lain”.

"Setelah pelatihan eksternal ada review mgenai pelatihan di hadapan temantemannya. Pimpinan mengamati kinerjanya kemudian. Misal materinya tentang pembiayaan, ada ringkasan analisa secara kuantitatif dan kualitatif, bisa dilihat sejauhmana dia mampu mengungkap/jeli melihat usaha nasabah".

"Tentu saja kami ingin tahu sejauhmana karyawan memahami materi pelatihannya. Jadi mereka diminta membuat resume atau ringkasan materi, diserahkan 
paling lambat 1 bulan setelah pelatihan berakhir".

\section{Promosi Jabatan}

Pada umumnya, penetapan promosi jabatan didasarkan pada prestasi kerja dan masa kerja karyawan. Indikator kinerja itu sendiri sudah jelas ditentukan dan diketahui oleh seluruh karyawan. Meskipun demikian peluang untuk promosi itu sendiri masih terbatas. Bank syariah yang bukan berupa bank umum, bisa dikatakan relatif baru dan masih terbatas wilayah operasinya, belum banyak atau bahkan belum ada kantor cabang pembantu. Belum lagi struktur organisasi pada kantor cabang yang tergolong 'flat', sehingga meskipun kebutuhan SDM ada kecenderungan meningkat, peluang promosi jabatan bagi karyawan yang sudah ada masih rendah. Di samping itu, kesiapan karyawan yang ada untuk memegang tanggung jawab yang lebih besar masih diragukan pihak manajemen. Hal ini membuat perusahaan berpikir ulang untuk mentransparansikan kriteria promosi jabatan, meskipun sebenarnya kriteria tersebut sudah ada. Sebagaimana pernyataan manajer berikut:

"Dasar penetapan promosi belum bisa ditransparansikan, krn ada trial and error, resiko tidak pasti. Misal seorang koordinator account officer yg akan dipromosikan menjadi kabag operasional, harus tahu berbagai hal seperti bagaimana mengatasi masalah. Dan perusahaan masih tidak yakin dia bisa tidak".

Pada bank syariah yang berupa bank umum maupun UUS, pemenuhan kebutuhan personil pada level eksekutif tidak selalu melalui rekrutmen internal. Rekrutmen eksternal terhadap para manajer dari bank konvensional biasa dilakukan, dengan sejumlah pertimbangan. Sebagaimana tanggapan sejumlah responden dalam pernyataan berikut:

"Mengingat bank-bank syariah yang belum lama usianya, memang di level eksekutif masih mengambil dari eksternal. Ada sih yang kita ambil dari bank konvensional, tapi dia juga punya pengetahuan syariah yang mumpuni. Karena kita lihat banyak yang terjebak di bank konvensional. Kita lebih melihat dari sisi hijrahnya, pengetahuan dia mengenai ilmu syariah, dan profesional".

“.....kami tidak perlu susah-susah mendidik dia. Kalau di bank syariah itu 2 pendidikannya, beda dengan konvensional. Kalau disana, mendidik kemampuan technical cukup dari sisi konvensional saja. Tetapi disini selaku bank syariah, pertama dididik pengetahuan konvensionalnya, supaya tahu halal haramnya baru pengetahuan syariahnya".

"Nah, itu kenapa kita mau ambil dari bank non syariah....karena dia sudah menguasai dulu syarat yang pertama. Kemampuan teknis operasional bank sudah menguasai, baru dimasuki pengetahuan syariahnya".

\section{Komunikasi}

Bank syariah yang menjadi responden pada penelitian ini menyatakan bahwa proses komunikasi baik formal maupun informal, lisan maupun tertulis terbilang lancar. Pengkomunikasian strategi, kebijakan, ataupun perubahan perusahaan pada karyawan, dilakukan melalui penetapan kebijakan tertulis dalam bentuk Surat Keputusan, Surat Edaran, Memo/Nota Dinas dan lain sebagainya yang disampaikan secara transparan. Kemudian kegiatan semacam doa pagi, briefing, atau pertemuan mingguan juga menjadi media berbagi pengalaman dalam melayani nasabah, mengkomunikasikan permasalahan pekerjaan dan sebisa mungkin memunculkan solusi. Sedangkan komunikasi informal terjalin melalui pertemuan seperti interaksi personal antara atasan dengan bawahan, pengajian dan olahraga bersama. Pengajian yang umumnya dilakukan sebulan sekali ditujukan untuk memberikan siraman rohani dan mengkaji nilai-nilai sikap kerja yang Islami. Dengan harapan sekaligus bisa memotivasi karyawan untuk lebih amanah dan tidak semata bersandar pada orientasi duniawi dalam menjalankan pekerjaannya. Pernyataan sejumlah manajer yang menggambarkan praktek komunikasi pada banknya, sebagai berikut:

"Diantara kami selalu merespon dengan cepat setiap informasi yang diberikan, 
baik dengan email, phone, maupun sms. Ini untuk mendukung budaya kerja responsif di sini".

"Kami melakukan pertemuan rutin tiap
pagi dan sore untuk Account Manager,
dan rutin tiap pagi bersamaan dengan doa
pagi untuk kru operasional".

"Ada keinginan memiliki tenaga kerja berkualitas unggul, namun yang demikian ada resiko turnover tinggi. Oleh karena itu semua level harus menguasai semua unit. Kami lebih cenderung membangun aspek keberkahan, menyentuh loyalitas dengan kesadarn internal karyawan melalui siraman rohani”.

\section{Kompensasi}

Pada umumnya komponen kompensasi pada bank responden mencakup gaji pokok, tunjangan-tunjangan, uang makan, uang transport, dan bonus tahunan. Adapun penetapan besaran gaji pokoknya mempertimbangkan keadilan internal dan eksternal. Secara internal, besaran berdasarkan pada masa kerja, deskripsi pekerjaan, dan prestasi kerja karyawan sebagaimana hasil PA (penilaian kinerja formal). Secara eksternal, bank juga memperhatikan daya saing kompensasinya dengan mempertimbangkan besaran gaji yang berlaku di bank lain, baik yang syariah maupun konvensional. Pada BUS dan UUS, benchmark eksternal terutama dengan bank konvensionalnya, karena sebagian karyawan berasal dari sana baik yang ditransfer oleh manajemen perusahaan maupun berdasarkan keinginan karyawan yang bersangkutan. Kecuali BUS seperti Bank Muamalat Indonesia (BMI) yang sejak pertama, berdiri sebagai bank umum syariah. Berikut pernyataan pimpinan bank umum syariah mengenai kebijakan kompensasi:

"Dalam menentukan struktur penggajian

kita menggunakan standar berdasarkan penilaian internal, yaitu berdasarkan job grading. Misal antara bagian marketing dan operation, lebih tinggi marketing. Namun standar internal kita juga mengacu pada eksternal....dalam hal ini bank ' $\mathrm{X}$ ' (ket: bank konvensionalnya)

dan juga harga yang berlaku di pasar".

Sedangkan BPRS, pembandingan eksternalnya adalah sesama BPR yang informasinya diperoleh dari forum Asbisindo. Beberapa informan mengakui bahwa masih kesulitan bagi mereka untuk mengikuti standar kompensasi bank umum. Sedangkan bank tersebut juga merupakan kompetitor bagi BPRS dalam mendapatkan dan mempertahankan input SDM berkualitas. Ketika peluang promosi jabatan juga terbatas, keterbatasan dalam menawarkan kompensasi yang kompetitif menjadi pemikiran tersendiri bagi bank syariah ini. Sebagaimana pernyataan beberapa pimpinan bank, sebagai berikut:

"Kendala yang dihadapi yang dirasakan selama ini, di dalam kebutuhan dan keinginan mendapat yang qualified, terkendala oleh bank besar. Di tengah jalan.....ternyata berpindah ke bank besar atau sedang dalam kondisi banyak pilihan. Dan gajipun menuntut tinggi di luar batas kemampuan perusahaan".

\section{Penilaian Kinerja}

Semua bank syariah dalam penelitian ini menyatakan bahwa telah menjalankan penilaian kinerja formal secara teratur tiap periode. Ada yang menjalankan setiap 3 bulan, dan beberapa bank lain melakukannya setiap 6 bulan sekali. Standar kinerja yang dievaluasi disusun oleh manajemen dan disosialisasikan kepada semua karyawan, sebagai acuan dan memotivasi karyawan untuk mencapai 'high performance'.

Indikator penilaian antara bank satu dengan yang lainnya bervariasi, namun pada dasarnya bisa dikelompokkan dalam indikator kemampuan kerja (sesuai deskripsi pekerjaan), sikap kerja, perilaku, dan kepribadian. Hasil penilaian lebih berorientasi pada tujuan administratif. Misal sebagai dasar penetapan atau penyesuaian gaji, dan pembagian bonus tahunan yang mana mengacu pada PA (performance appraisal) tahunan. Selebihnya, hasil penilaian kinerja karyawan secara individual kurang mendukung tujuan pengembangan bagi karyawan yang bersangkutan. Misal, tidak ada kaitannya PA karyawan dengan kesempatan training formal ataupun peluang promosi. 
Umumnya pihak yang memberikan penilaian adalah atasan. Sedang pada bank umum syariah, karyawan juga diberi hak untuk melakukan self-assessment berikut argumen atas penilaian terhadap diri sendiri tersebut. Pada beberapa bank, umpan balik penilaian juga diberikan agar terjadi continuous improvement, yang mana ini menjadi salah satu tujuan evaluasi. Berikut tanggapan beberapa pimpinan bank yang dirangkum dalam pernyataan:

"Hasil penilaian hanya diketahui oleh atasan dan karyawan yang bersangkutan. Satu-satu dipanggil atasan untuk konseling secara individual. Kamu bagusnya disini kurangnya disana, sekaligus memberikan feedback.

Di satu sisi, intensitas interaksi yang cukup tinggi meningkatkan kedekatan hubungan antara atasan dan bawahan pada bank syariah. Namun di sisi yang lain bisa menimbulkan inflasi penilaian karena keengganan berkonflik dengan bawahan. Hal ini menyebabkan praktek penilaian kinerja cenderung formalitas dan kurang berimplikasi pada pengembangan karyawan. Ketidaktersediaan data kinerja karyawan juga menjadi keterbatasan atasan dalam melakukan evaluasi. Belum lagi penilaian terhadap kinerja obyektif maupun subyektif yang menuntut sumber daya waktu atasan. Hasil PA yang kurang akurat tidak bisa menjadi acuan promosi karyawan secara fair. Itulah kenapa sebagian besar responden karyawan mempersepsikannya sekedar untuk kepentingan administratif, dan bukan pengembangan karyawan. Sebagaimana pernyataan pimpinan bank responden berikut:

"Dalam melakukan identifikasi kekurangan dari kinerja pegawai, terkadang reaksi yang ditimbulkan cenderung negatif. Sehingga pegawai yang dinilai tidak bisa menerima saran-saran untuk menghadapi masalah-masalah di masa mendatang. Elemen lainnya adalah ketidaksiapan penilai. Untuk mereview kinerja seorang pegawai idealnya penilai/atasan harus mempunyai waktu yang cukup untuk mereview dan mengevaluasi kinerja selama periode waktu yang diperlukan dan setidaknya telah memiliki catatan periodik tentang kinerja pegawai secara mingguan/bulanan".

\section{Pembahasan}

Dalam kaitan antara praktek MSDM dengan kinerja, cenderung menggunakan pendekatan contingency yang mendasarkan pada premis bahwa kebijakan SDM perlu disesuaikan dengan konteks yang mana bisa mendatangkan efek menguntungkan. Hal ini mempengaruhi kebijakan yang diambil pada praktek pengelolaan karyawan yang ada. Kemenduaan mekanisme yang dijalankan dalam suatu praktek, misalnya pada praktek seleksi, berimplikasi pada kriteria kinerja yang lebih memperhitungkan prestasi hasil dibandingkan proses.

Sebagian praktek dan kebijakan pengelolaan SDM pada perbankan syariah dalam penelitian ini sudah optimal, dan sebagian yang lain belum. Cut-off point yang digunakan untuk menentukan suatu praktek sudah optimal, adalah nilai mean indikator yang lebih dari 3,9 dan skor minimal 3. Dengan mengacu cut-off point tersebut, beberapa indikator yang perlu diperhatikan dan musti diupayakan perusahaan untuk ditingkatkan adalah indikator-indikator pada praktek rekrutmen dan seleksi, pelatihan dan pengembangan, promosi jabatan, kompensasi, dan penilaian kinerja. Sedangkan praktek formalisasi kebijakan sudah berjalan dengan optimal.

Berikut adalah indikator-indikator yang masih harus dioptimalkan. Pada praktek rekrutmen dan seleksi, perusahaan harus memberikan prioritas kepada karyawan yang sudah ada dalam memenuhi peluang jabatan strategis, daripada melakukan rekrutmen eksternal. Pada saat seleksi, perusahaan juga harus mendefinisikan pekerjaan dengan jelas. Bagaimana kualitas dan kreativitas perusahaan dalam melakukan seleksi akan sangat menentukan outcomes organisasional ke depan. Sebagaimana dinyatakan oleh Becker and Huselid (1992), bahwa selektivitas pada perekrutan dan pemilihan karyawan berhubungan positif dengan kinerja perusahaan.

Pada praktek pelatihan dan pengembangan, perusahaan musti mendesain dan mengembangkan metode, teknik dan kriteria evaluasi pelatihan dengan baik. Perusahaan 
juga harus memberikan konseling mengenai perencanaan karir karyawan, meskipun pelaksanaannya dilakukan secara personal antara karyawan dengan atasan langsungnya. Material pelatihan didesain dan dijalankan dengan baik, kebutuhan pelatihan dianalisis dengan baik, dan program pelatihan terjadwal dan disosialisasikan, alokasi waktu pelatihan dan frekuensi pelaksanaan pun musti mendukung kebutuhan karyawan. Kesemua indikator itulah yang belum dijalankan secara optimal pada bank syariah dalam penelitian ini. Sedangkan menurut Knoke and Kalleberg (1994), organisasi dapat meningkatkan kualitas karyawan melalui training yang komprehensif dan aktivitas pengembangan pasca seleksi. Investasi pada praktek tersebut terbukti menghasilkan outcomes yang menguntungkan bagi organisasi. Temuan tersebut didukung pula oleh Xiao (1996), yang menyatakan bahwa pelatihan merupakan cara yang tepat untuk mengatasi faktor-faktor yang menurunkan kepuasan kerja dan kinerja karyawan. Tentunya pelatihan itu sendiri perlu direncanakan dan diimplementasikan dengan tepat, mulai dari identifikasi hingga evaluasi pelaksanaannya.

Pada praktek promosi jabatan, faktor fairness dan dasar penetapan promosi merupakan indikator yang masih belum bisa diterima dengan baik oleh karyawan. Pada kenyataannya memang mempekerjakan karyawan berkualitas dari luar perusahaan itu lebih mudah dibandingkan perusahaan harus mengeluarkan dana ekstra untuk mengadakan pelatihan. Pengeluaran untuk itu lebih dianggap sebagai biaya, bukannya investasi. Hal tersebut didukung oleh hasil studinya Miah and Bird (2007) yang dilakukan di sejumlah perusahaan kecil dan menengah di negara dunia ketiga.

Sedangkan pada praktek komunikasi, kesediaan atasan menerima masukan dan forum informal di atara karyawan merupakan indikator yang belum optimal pelaksanaannya. Padahal sejauhmana aktivitas tim pada perusahaan mampu meningkatkan kerjasama dan komunikasi diantara anggota organisasi, akan menentukan terciptanya budaya kerja yang mendukung penguatan nilai-nilai positif perusahaan (Kaya, 2006). Kemudian pada praktek kompensasi, faktor keadilan dalam penetapan besaran, daya saing kompensasi dibandingkan bank lain, dan kinerja sebagai dasar peningkatan gaji/bonus, merupakan indikator yang masih belum optimal.

Akhirnya, praktek penilaian kinerja pun bisa disimpulkan belum optimal. Sebab hasil penilaiannya masih sekedar untuk kepentingan administratif, belum mendukung pengembangan karyawan. Temuan ini tidak sejalan dengan pernyataan Stone (1998), bahwa umpan balik terhadap hasil penilaian kinerja merupakan praktek yang dibutuhkan atasan maupun bawahan yang dinilai guna meningkatkan efektivitas kerja. Ini merupakan cara meningkatkan komunikasi diantara keduanya. Berbagi informasi dan mendiskusikan kinerja individual karyawan akan membentuk keterbukaan organisasional, sehingga meningkatkan loyalitas, perilaku kooperatif dan trust karyawan pada perusahaan.

Pemimpin memainkan peran kunci dalam memengaruhi persepsi para karyawannya terhadap dukungan organisasi (Wikaningrum, 2006). Sebab pemimpin seringkali merupakan "distributor" bagi discretionary rewards dari organisasi. Atasan langsung juga berpeluang membantu peningkatan gaji misalnya melalui penilaian kinerja yang mereka berikan, dan memberikan saran bagi manajemen karir bawahan. Pemimpin juga dipersepsikan berperan dalam penugasan, memberikan peluang pelatihan, dukungan emosional serta informasi terkait dengan pelaksanaan pekerjaan. Ketika atasan langsung tersebut dipersepsikan sebagai representasi dari organisasi, maka sifat hubungan atasanbawahan akan semakin efektif dalam mempengaruhi kepercayaan karyawan terhadap organisasinya.

Hubungan pertukaran sosial lebih didasarkan pada kepercayaan individual, bahwa pihak lain pada hubungan tersebut akan menjalankan kewajibannya secara adil. Oleh karena itu perlu ditumbuhkan trust dalam hubungan antar anggota organisasi, baik antara pemimpin dengan bawahan maupun di antara bawahan itu sendiri. Mengingat pemimpin memiliki peran penting dalam jaringan pertukaran pada suatu organisasi, maka hal ini meningkatkan pemahaman bahwa setiap pemimpin hendaknya membentuk hubungan kualitas tinggi (in-group) dengan setiap anggotanya. Hubungan pertukaran yang adil dengan segenap bawahan diharapkan akan membentuk hubungan pertukaran antar 
karyawan yang positif, yang pada gilirannya ikut menentukan sikap kerja yang positif. Lebih lanjut, bagaimana pemimpin mengembangkan hubungan pertukaran dengan segenap bawahannya tersebut akan menentukan kemampuannya mengintegrasikan karyawan ke arah pencapaian tujuan organisasi melalui terbentuknya persepsi positif akan dukungan organisasi terhadap mereka.

Relatif besarnya jumlah karyawan pada penelitian ini yang rendah kepercayaannya baik kepada atasan maupun organisasinya, nampaknya bisa dipahami jika kepuasan kerja dan komitmen karyawan pada organisasinya yang ternyata juga cukup rendah. Sebagaimana hasil studi sebelumnya yang menunjukkan bahwa "trust" akan memengaruhi besarnya sikap kerja karyawan, seperti kepuasan kerja dan komitmen organisasional (Wikaningrum, 2007).

Ada hubungan antara dunia kerja dengan dunia pendidikan. Ketidaktersediaan sumber daya manusia di pasar tenaga kerja yang memiliki kompetensi sesuai kebutuhan industri, terkait erat dengan keberadaan program studi dan kurikulum pada lembaga pendidikan yang ada. Begitupula pada perbankan syariah, semua bank responden pada penelitian ini menyatakan kesulitannya mendapatkan karyawan yang memahami prinsip-prinsip operasionalisasi syariah Islam. Program studi perbankan syariah dan kurikulum terkait pada lembaga pendidikan tinggi yang ada di Indonesia, masih sangat terbatas jumlahnya. Sedangkan data dari Bank Indonesia menunjukkan bahwa rata-rata pertumbuhan penyerapan pegawai bank syariah per tahun sebesar $22,8 \%$. Tak pelak lagi terjadi ketidakseimbangan antara permintaan dan penawaran karyawan sesuai kebutuhan. Hal ini yang kemudian menjadi tantangan sekaligus tanggung jawab perbankan syariah untuk bagaimana mendesain dan menjalankan program pelatihan sedemikian rupa, agar bisa menambah ilmu, keahlian, dan sikap kerja Islami pada sumber daya insaninya. Sebagaimana dinyatakan dalam surat Jumu'ah (62): 2, yang berbunyi:

Dia lah yang mengutus kepada kaum yang buta huruf seorang Rasul di antara mereka, yang membacakan ayat-ayat-Nya kepada mereka, mensucikan mereka dan mengajarkan mereka Kitab dan Hikmah (As Sunnah). Dan sesungguhnya mereka sebelumnya benar-benar dalam kesesatan yang nyata.

Secara internal, bank syariah perlu meningkatkan pengetahuan mengenai syariah Islam pada para karyawannya, sehingga terbentuk individu-individu yang sanggup memikul amanah dan beban kerja yang diberikan perusahaan. Secara eksternal, aset SDM yang demikian akan membantu bank syariah memiliki human capital yang profesional guna memenangkan persaingan di dalam industri perbankan syariah itu sendiri maupun perbankan nasional pada umumnya. Sebagaimana diketahui perkembangan jumlah perbankan syariah yang cukup signifikan beberapa tahun terakhir, baik yang berupa bank umum syariah (BUS), Unit Usaha Syariah (UUS) pada bank konvensional, terlebih lagi BPR Syariah yang jauh lebih besar lagi jumlahnya dan tersebar di berbagai kota di Indonesia. Agar unggul dalam persaingan, tidak bisa dihindarkan lagi peran pelatihan dan pengembangan karyawan pada bank syariah guna menanggapi keterbatasan kualitas SDM di pasar tenaga kerja. Sebagaimana secara tegas termuat pada surat Al Mujaadilah (58): 11, yang berbunyi:

Hai orang-orang beriman apabila dikatakan kepadamu: "Berlapang-lapanglah dalam majlis", maka lapangkanlah niscaya Allah akan memberi kelapangan untukmu. Dan apabila dikatakan: "Berdirilah kamu", maka berdirilah, niscaya Allah akan meninggikan orangorang yang beriman di antaramu dan orang-orang yang diberi ilmu pengetahuan beberapa derajat. Dan Allah Maha Mengetahui apa yang kamu kerjakan.

\section{PENUTUP}

Hasil penelitian menunjukkan kurang optimalnya pelaksanaan praktek pengelolaan SDM di sebagian besar responden bank syariah. Yakni pada alokasi waktu pelatihan dan frekuensi pelaksanaannya, kejelasan dasar penetapan promosi jabatan, jenis dan besaran kompensasi yang kurang kompetitif jika dibandingkan dengan jenis pekerjaan yang sama di bank lain, 
dan penilaian kinerja yang kurang berorientasi pada pengembangan karyawan. Landasan hukumnya sudah baik, namun dari sisi pelaksanaan masih belum kaffah. Ketika ketersediaan input SDM di pasar tenaga kerja memiliki keterbatasan pengetahuan syariah Islam, para pelaku perbankan syariah sebenarnya meyakini bahwa pengembangan kapabilitas karyawan melalui HRM practices bundle menjadi kebutuhan krusial. Namun pemahaman akan hal tersebut kurang diimbangi dengan praktek seleksi, pelatihan dan pengembangan, promosi jabatan, komunikasi, kompensasi, dan praktek penilaian kinerja yang terintegrasi satu dengan lainnya.

Temuan menarik lainnya, meskipun dari sisi pelaksanaan masih belum optimal namun kinerja SDMnya dinilai cukup baik oleh pihak manajemen. Rendahnya tingkat komplain nasabah mendasari keyakinan pimpinan akan penilaian baik tersebut. Meskipun diakui bahwa pemahaman pengetahuan syariah dan kemampuan menjelaskan produk/jasa syariah merupakan indikator kinerja yang dinilai masih belum optimal. Sehingga dapat disimpulkan bahwa persepsi kinerja SDM menurut bank syariah pada penelitian ini, menggunakan pendekatan kualitas hasil ketimbang kualitas proses. Hal ini tidak sejalan dengan prinsip syariah itu sendiri yang mana dalam melakukan kegiatan yang berhubungan dengan muamalat, kaum muslimin wajib berpegang teguh pada peraturan dan hukum yang ditetapkanNya.

Bagi perbankan syariah, hendaknya mengkaji ulang efektifitas kebijakan pengelolaan SDM dan implementasinya terhadap pencapaian kinerja organisasi. Kegiatan dalam masing-masing praktek pengelolaan SDM hendaknya saling terkait dan mendukung satu sama lain. Adanya konfigurasi tersebut secara efektif bisa menimbulkan efek sinergistik yang tidak hanya akan mengarahkan perilaku dan memotivasi karyawan, namun juga meningkatkan trust mereka kepada perusahaan. Dampaknya bagi sejumlah outcome organisasional seperti komitmen organisasional dan kepuasan kerja pun akan lebih positif.

Bagi penelitian selanjutnya, perlu mempertimbangkan persepsi karyawan mengenai dukungan perusahaan dan komitmen afektif sebagai variabel yang memoderasi hubungan antara persepsi mengenai praktek MSDM dengan kinerja. Kemudian, dalam mengembangkan model konfigurasi ideal yang akan menjadi "best practices" dalam pengembangan SDM, perlu memperhatikan harapan karyawan akan kebutuhan pengembangan mereka dan mempertimbangkan kendala perusahaan dalam implementasinya. Hal ini tidak hanya akan memperkuat persepsi karyawan bahwa praktek dan kebijakan yang diterapkan perusahaan tidak semata mengejar kepentingan organisasional, namun juga menjamin efektivitas pelaksanaan praktek pengelolaan tersebut.

\section{DAFTAR PUSTAKA}

Aryee, S., PS. Budhwar and ZX. Chen. 2002. Trust as a Mediator of the Relationship Between Organizational Justice and Work Outcomes: Test of a Social Exchange Model. Journal of Organizational Behavior. 23. 267-85.

Becker and Huselid. 1992. Direct Estimates of SD, and The Implication for Utility Analysis. Journal of Applied Psychology. 77. 227-233.

Crouch, A. and P. Yetton. 1988. Manager Subordinate Dyads: Relationship Among Task and Social Contact, Manager Friendlines and Subordinate Performance in Management Group. Organizational Behavior and Human Decision Processes. 41. 65-82.

De Saa-Perez, P. and JM. Garcia-Falcon. 2002. A Resource-based View of Human Resource Management and Organizational Capabilities Development. International Journal of Human Resource Management. 13. 123-40.

Eisenberger, R., PM. Fasolo and V. DavisLaMastro. 1990. Effects of Perceived Organizational Support on Employee Diligence, Innovation, and Commitment. Journal of Applied Psychology. 53. 51-59.

Gouldner, AW. 1960. The Norm of Reciprocity: A Preliminary Statement. American Sociological Review. 25. 161-79.

Guest, D. 1997. Human Resource Management and Performance: A Review and 
Research Agenda. The International Journal of Human Resource Management. 8 (3). 263-76.

Lau, ML. and H. Ngo. 2004. The HR System, Organizational Culture and Product Innovation. International Business Review. 13. 685-703.

Liden, RC. and G. Graen. 1980. Generalizability of the Vertical Dyad Linkage Model of Leadership. Academy of Management Review. 23 (3). 451-465.

Liden, RC., SJ. Wayne and D. Stilwell. 1993. A Longitudinal Study on the Early Development of Leader-Member Exchanges'. Journal of Applied Psychology. 78. 662-74.

Kaya, N. 2006. The Impact of Human Resource Management Practices and Corporate Entrepreneurship on Firm Performance: Evidence From Turkish Firms. International Journal of Human Resource Management. 2074-2090.

Knoke and Kalleberg. 1994. Job Training in U.S. Organization. American Sociological Review. 59. 537-546.

Konovsky, MA. and SD. Pugh. 1994. Citizenship Behavior and Social Exchange. Academy of Management Journal. 37(3). 656-669.

Mayer, RC. and JH. Davis. 1999. The Effect of the Performance Appraisal System on Trust for Management: A Field QuasiExperiment. Journal of Applied Psychology. 84(1). 123-136.

Miah, MK. and A. Bird. 2007. The Impact of Culture on HRM Styles and Firm performance: Evidence From Japanese Parents, Japanese Subsidiaries/Joint Ventures and South Asian Local Companies. International Journal of Human Resource Management. 908923.

Mowday, RT., RM. Steers and LW. Porter. 1979. The Measurement of Organizational Commitment. Journal of Vocational Behavior. 14. 224-247.
Prusak, L. and D. Cohen. 2001. How to Invest in Social Capital. Harvard Business Review. 79(6). 86-93.

Rosse, JG. and AI. Kraut. 1988. Reconsidering the Vertical Dyad Linkage Model of Leadership. Journal of Occupational Psychology. 61. 63-71.

Scandura, TA., GB. Graen and MA. Novak. 1986. When Managers Decide Not to Decide Autocratically: An Investigation of Leader-Member Exchange and Decision Influence. Journal of Applied Psychology. 87 (3).

Schnake, ME. 1983. An Empirical Assessment of the Effect of Affective Response of The Measurement of Organizational Climate. Personnal Psychology. 36. 371-807.

Schneider, B. and D. Bowen. 1985. Employee and Customer Perceptions of Service in Banks: Replication and Extension. Journal of Applied Psychology. 70(3). 423-433.

Schneider, B. and D. Bowen. 1993. The Service Organization: Human Resources Management is Crucial. Organizational Dynamics, 21(4), 3952.

Sherony, KM. and SG. Green. 2002. Coworker Exchange: Relationships Between Coworkers, Leader-Member Exchange, and Work Attitudes. Journal of Applied Psychology. 87 (3).

Tzafrir, SS. and LS. Dolan. 2004. Trust ME: A Scale for Measuring Employee Manager Trust. Journal of Management Research. 2(2). 117-134.

Tzafrir, SS. and ABA. Gur. 2007. HRM Practices and Perceived Service Quality: The Role of Trust as a Mediator. Research and Practice in Human Resource Management, 15(2), 1-20.

Vecchio, RP. and BC. Gobdel. 1984. The Vertical Dyad Linkage Model of Leadership: Problems and Prospects. Organizational Behavior and Human Performance. 34. 5-20. 
Wayne, SJ. and GR. Ferris. 1990. Influence Tactics, Affect, and Exchange Quality in Supervisor-Subordinate Interactions: A Laboratory Experiment and a Field Study. Journal of Applied Psychology. 75. 487-499. Wayne, SJ., LM. Shore and RC. Liden. 1997. What's Loyalty? Perceived Organizational Support and Leader-Member Exchange: A Social Exchange Perspective. Academyof Management Journal. 40. 82-111.

Whitener, EM. 2001. Do "High Commitment" Human Resource Practices Affect Employee Commitment? A CrossLevel Analysis Using Hierarchical Linear Modelling. Journal of Management. 27. 515-35.

Wikaningrum, T. 2006. Pertukaran Sosial dalam Organisasi: Peran Pemimpin dalam Pembentukan Sikap Kerja. Prosiding Semiloka Nasional
Departemen Manajemen Fakultas Ekonomi dan Manajemen IPB. ISBN: 979-15424-0-6.

Wikaningrum, T. 2007. Coworker Exchange, Leader-Member Exchange, and WorkAttitudes: a Study of Coworker Dyads. International Journal of Business. 9. 187-215.

Xiao, J. 1996. The Relationship between Organizational Factors and the Transfer of Training in the Electronics Industry in Shenzhen, China, Human Resource Development Quarterly. 7(1). 55-73.

Zerbe, WJ., D. Dobni and GH. Harel. 1998. Promoting Employee Service Behaviour: The Role of Perceptions of Human Resource Management Practices and Service Culture. Canadian Journal of Administrative Sciences. 15 (2). 165-179. 